\title{
Integrated assessment of contaminants and monitoring of an urbanized temperate harbor (Montevideo, Uruguay): a 12-year comparison
}

\author{
Pablo Muniz ${ }^{1}$, Natalia Venturini ${ }^{l}$, César C. Martins' ${ }^{2}$,Alia Bano Munshi ${ }^{3}$, Felipe García-Rodríguez ${ }^{1}$,

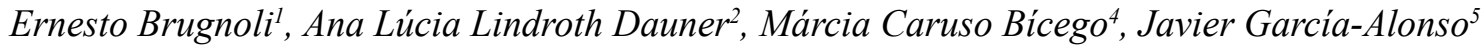

\author{
1 Oceanografía \& Ecología Marina, Instituto de Ecología y Ciencias Ambientales (IECA), Facultad de Ciencias, Universidad de la Re- \\ pública (UdelaR). \\ (Iguá 4225 Montevideo 11400, Uruguay) \\ 2 Universidade Federal do Paraná. \\ 3 Centre of Environmental Studies of Pakistan. \\ 4 Instituto Oceanográfico da Universidade de São Paulo.
}

5 CURE- Maldonado, UdelaR.

*Corresponding author: pmmaciel@fcien.edu.uy

\section{Abstract}

Situated opposite the Freshwater Front, Montevideo city with its more than 1.5 million inhabitants encircles Montevideo Bay, where one of the most active and polluted harbors in South America is located. Faecal sterols, trace metals, organochlorine compounds and petroleum derivatives in the sediments of Montevideo Harbor were evaluated and their spatial distribution inside the harbor as well as in the input of two main tributary streams analyzed. Specifically for the harbor sites, a temporal comparison of metal and hydrocarbons was made with previous measurements taken 12 years ago. Clear changes were observed at these sites. The concentration of metals such as $\mathrm{Pb}, \mathrm{Cr}$ and $\mathrm{Zn}$ have diminished, while aliphatic hydrocarbons have increased their values at almost all of the stations studied. Differences were observed between summer and winter suggesting sedimentation, input or hydrodynamic changes in the area. These results help one to understand the present situation and develop the management measures needed to improve the environmental quality of the harbor and bay.

Descriptors: Organic and inorganic pollutants, Sediment, Estuary, Pollution monitoring, Río de la Plata.

\section{RESUMO}

A cidade de Montevidéu, com mais de 1,5 milhões de habitantes, circunda a Baía de Montevidéu, onde um dos portos mais ativos e poluídos da América do Sul está localizado. No presente trabalho, foram avaliados esteróis fecais, metais traço, compostos organoclorados e derivados de petróleo nos sedimentos superficiais do Porto de Montevidéu, analisando sua distribuição espacial no interior do porto, bem como em dois dos principais tributários que chegam ao interior da baía. Especificamente para os sítios do porto, foi realizada uma comparação temporal dos metais pesados e hidrocarbonetos, considerando dados pretéritos de 12 anos. Foram observadas alterações significativas nos sítios estudados. Metais, tais como o $\mathrm{Pb}, \mathrm{Cr}$ e $\mathrm{Zn}$, apresentaram redução nas suas concentrações, enquanto os hidrocarbonetos alifáticos aumentaram seus valores em quase todas as estações. Foram observadas também diferenças entre o verão e o inverno, sugerindo mudanças no padrão de sedimentação, nos ingressos de substâncias e/ou mudanças hidrodinâmicas na área. Os resultados podem vir auxiliar na compreensão do estado atual e para o desenvolvimento de medidas de gestão necessárias para melhorar a qualidade ambiental do porto e da baía.

Descritores: Poluentes orgânicos e inorgânicos, Sedimentos, Estuário, Monitoramento, Rio da Prata. 


\section{INTRODUCTION}

The degradation of coastal ecosystems due to population growth, the expansion of industrial and agricultural activity, and global climate change, has become a global issue (LOTZE et al., 2006; AIROLDI and BECK, 2007; WAYCOTT et al., 2009). Among coastal ecosystems, estuaries and/or semi-enclosed bays are among the most important marine ecosystems in the world, both in terms of biological production and for the development of human activities. These areas, known as marine/freshwater transition regions, are particular environments because their physico-chemical conditions fluctuate and biological processes must cope with these fluctuations, which is a cause of stress. Moreover, due to poor water exchange in semi-enclosed bays (LIM et al., 2012), a decline in ecosystem health is to be expected as a consequence of the increased pollutant concentrations.

Estuaries are priority areas for the study of environmental pollution (DUCROTOY and ELLIOT, 2006). Since the sediments settle, these systems involve large amounts of organic matter - including pollutants. Over the past several decades, estuaries and semi-enclosed bays have been significantly affected by anthropogenic actions, such as the occupation of areas for urban, industrial and port development, wastewater discharge, and oil spills (CADDY, 2000; SHI et al., 2011; PENG et al., 2012). Seawater quality has deteriorated gradually, due to the increase of contaminants and exogenous substances. Among these, trace metals, polycyclic aromatic hydrocarbons (PAHs), polychlorinated biphenyls (PCBs) and organochlorine pesticides (OCPs) are very persistent compounds which result in oxidative stress and possess genotoxic and endocrine disrupter properties (GORSKI et al., 2003; BOLL et al., 2010; UNEP, 2012). Therefore, the sources and fate of these organic pollutants in the environment and the biogeochemical processes involving them are of key relevance for an adequate environmental management program.

Trace metals and metalloids are persistent pollutants since they cannot be degraded and they, therefore, accumulate in estuarine sediments. There are several sources of these elements, e.g. historical and present-day mining activities, industrial areas, smelters, combustion by-products, and traffic. (LUOMA and RAINBOW, 2008). The ecotoxicological risk due to the metal-polluted sediments will depend on the metals' partitioning and bioavailability, as well as on the ability of organisms to assimilate metals (CARDOSO et al., 2009). Metals such as cadmium $(\mathrm{Cd})$, chromium $(\mathrm{Cr})$, cobalt $(\mathrm{Co})$, lead $(\mathrm{Pb})$, nickel $(\mathrm{Ni})$, copper $(\mathrm{Cu})$ and zinc $(\mathrm{Zn})$ and the metalloid arsenic (As), are toxic elements that accumulate in the sediments of estuaries and can affect biological processes in the associated fauna (LUOMA and RAINBOW, 2008).

Aliphatic hydrocarbons (AHs) such as n-alkanes and unresolved complex mixtures (UCM) and the PAHs present in sediments have been used to assess petroleum and petroleum by-product contamination in estuarine environments (MARTINS et al., 2007; SILVA and BÍCEGO, 2010). Urban runoff, sewage disposal, industrial effluents, oil production and transport activities are some of the most important sources of anthropogenic hydrocarbons (KIM et al., 1999). PAHs are derived mainly from anthropogenic sources such as the combustion of fossil fuels and the direct release of oil and by-products, with a smaller contribution coming from forest fires and agricultural burn-off (LAW and BISCAYA, 1994). PAHs are rarely found as biosynthetic products and have a high toxicity for organisms due to their carcinogenic and mutagenic potential (UNEP, 1992).

PCBs and OCPs are persistent organic pollutants (POPs) historically discharged as a result of industrial and agricultural activities, respectively. All these chemicals can affect the natural condition of the faunal community. In estuaries, their presence has been associated with high sediment toxicities (GARCÍA-ALONSO et al., 2011). PCBs have been used as a flame retardant in plastics, while organochlorine pesticides are widely disseminated in natural environments after use for pest control (COMBI et al., 2013).

Faecal sterols, such as coprostanol and epicoprostanol, have previously been used as tracers for human waste in sediments of coastal areas worldwide (e.g. MUDGE and DUCE, 2005; MARTINS et al., 2012a; MARTINS et al., 2014, Venturini et al., 2015). They are persistent in sediments, easily associate with particulate material and sediments, and present notable resistance to anaerobic degradation. Sewage pollution derived from densely populated areas around ports has been evaluated more recently by high concentrations of faecal sterols (PENG et al., 2005; MARTINS et al., 2010; 2011a; ALBANO et al., 2013).

Montevideo Bay is located in a key transitional part of the complex Rio de la Plata estuarine system, the second largest estuary in South America and the fourth in the world. Situated opposite the freshwater front, 
Montevideo city with more than 1.5 million inhabitants surrounds Montevideo Bay, where the most active and polluted harbor of Uruguay is located (DANULAT et al., 2002; MUNIZ et al., 2004). PAH-ratios as well as $n$ -alkane concentrations show that the main local source of hydrocarbons is petroleum and its derivatives, the elevated proportions of Unresolved complex mixture (UCM) pointing to long-term petroleum contamination (MUNIZ et al., 2004). At the levels present in 1998, within the inner harbor region where water exchange is reduced, $\mathrm{Cd}, \mathrm{Zn}, \mathrm{Cu}, \mathrm{Cr}, \mathrm{Pb}, \mathrm{Ag}$ and $\mathrm{Hg}$ may cause major adverse biological effects (MUNIZ et al., 2004, DANULAT et al., 2002). During the last decade several changes have occurred, including a close-down of the discharge of domestic sewage, a decrease in industrial effluents into the Pantanoso and Miguelete streams, and an expansion of the harbor. Land reclamation can cause damage to benthic communities (causing mass macrobenthos death, BORJA et al., 2009) and the reduction of the tidal prism that in turn would decrease the hydrodynamic force of the bay and increase sediment deposition. On the other hand, there has been a decrease in heavy metal concentrations and biochemical oxygen demand (BOD) values in the bay, associated with the discharges of the streams that flow into the bay (IMM, 2008). In this area, BOD showed a reduction of $48 \%$, while $\mathrm{Pb}$ and $\mathrm{Cr}$ showed a reduction of 95 and 97\%, respectively, over the last ten years (IMM, 2008). The total industrial effluent load in the coastal zone of Montevideo has undergone a considerable reduction in the last ten years. In fact, the $\mathrm{Cr}$ and $\mathrm{Pb}$ loads released by local industries in 1999 were 439 and $47 \mathrm{~kg}^{\text {day }}{ }^{-1}$ respectively, while at the present time they are less than 65 and $4.8 \mathrm{~kg}$ day $^{-1}$ of $\mathrm{Cr}$ and $\mathrm{Pb}$, respectively (IMM, 2009).

The purposes of this study were: (1) to quantify and evaluate the spatial distribution of trace metals, hydrocarbons, PCBs and faecal sterols in the modern sediments of Montevideo Harbor; (2) to investigate the natural and anthropogenic processes controlling sedimentary contaminants, and (3) to identify changes, if any, in the hydrocarbon and trace metal loads over the last 12 years, when the first integrative assessment in the same area was undertaken.

\section{MATERIAL AND METHODS}

\section{SAMPLE COLLECTION}

Sediments were collected from 8 different sites Montevideo harbour, and four sites in the two streams that flow into the bay (Fig. 1). Sampling was carried out twice a year, in austral summer and winter (January and August 2010, respectively). Stations A (5 m depth), B (7 m) and D $(2 \mathrm{~m})$ represented the harbour entrances, while stations $\mathrm{H}$ and $\mathrm{C}$ ( $6 \mathrm{~m}$ both) corresponded to intermediate locations. Stations $\mathrm{G}(10 \mathrm{~m})$ and $\mathrm{F}(9 \mathrm{~m})$ were more coastal sites in basins I and II, respectively; station E (5 m) was located just off the fisheries dock. This design was adopted in order to allow comparison with previous studies undertaken in the area. The four stations in the streams were positioned at the mouth of each stream and $5 \mathrm{~km}$ up it.

Sediment samples were taken with a van Veen grab $\left(0.05 \mathrm{~m}^{2}\right)$ and a Kajac-corer (acrylic core, $4.5 \mathrm{~cm}$ internal diameter), and only the top $3 \mathrm{~cm}$ of undisturbed surface sediment were considered for all the analyses carried out in the laboratory. The samples were used for: one sample (approx. $100 \mathrm{gr}$ ) for granulometric analysis; three other samples stored in polyethylene vials in the cold $\left(4^{\circ} \mathrm{C}\right)$ for quantification of organic matter and photosynthetic pigments; sediments contained in the other three grab samples were transferred to precleaned aluminium bottles and frozen until the analysis of hydrocarbons, PCBs and faecal sterols, and finally one acrylic corer was stored in the cold and used for trace metal determinations.

GRANULOMETRIC, TOTAL ORGANIC MATTER, PIGMENT, CARBOHYDRATE AND PROTEIN ANALYSES

Grain size analysis was performed using the "Lowangle laser light scattering" method with a "Droplet and Particle Analyser - Malvern" series 2600. Frequency and size classes were calculated in accordance with SUGUIO (1973). Sub-samples of 1.5-2.0 g were analysed for total organic matter (TOM) by weight loss on ignition at 550 ${ }^{\circ} \mathrm{C}$ for $4 \mathrm{~h}$ following HEIRI et al. (2001). Photosynthetic pigment (chlorophyll- $a$ and phaeopigments) content was determined in accordance with LORENZEN (1967) modified by SUNBACK (1983). Total protein (PRT) analysis was conducted following extraction with $\mathrm{NaOH}\left(0.5 \mathrm{~mol} \mathrm{~L}^{-1}, 4 \mathrm{~h}\right)$ and determined in accordance with HARTREE (1972) as modified by RICE (1982) to compensate for phenol interference. Total carbohydrates (CHO) were analysed according to GERCHACOV and HATCHER (1972). Blanks for each analysis were performed with pre-combusted sediments at $450-480{ }^{\circ} \mathrm{C}$ for $4 \mathrm{~h}$. PRT, and CHO concentrations were expressed as bovine serum albumin (BSA) and glucose equivalents, respectively. 


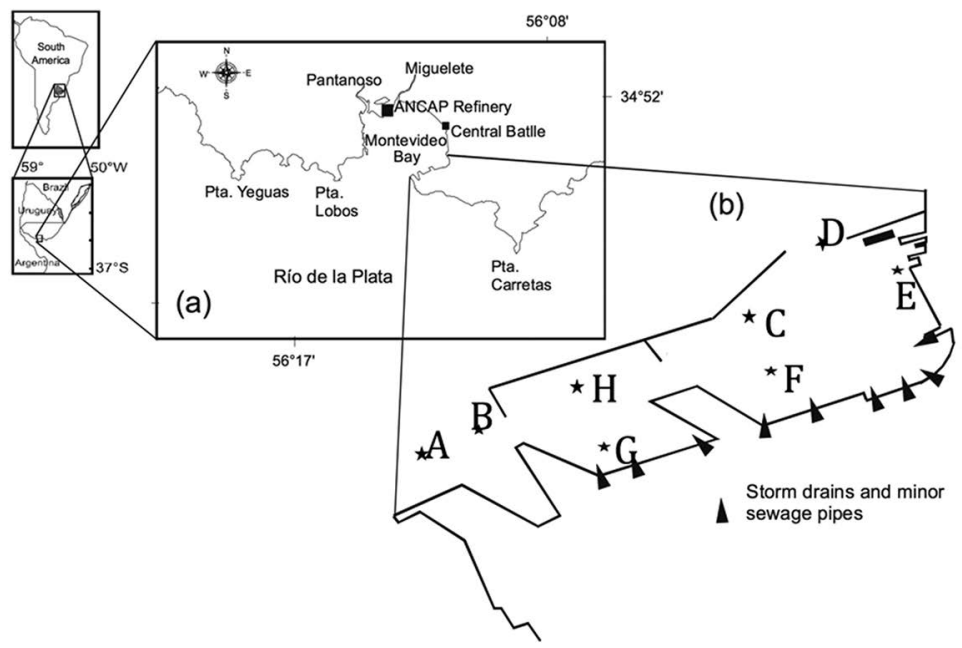

Figure 1. Location of (a) Montevideo Bay, and (b) the eight stations (*) of Montevideo Harbour (marked A to H) sampled in Summer and Winter 2010. The black arrows indicate the principal sewage pipes and storm drains that discharge into the harbour basins (Modified from MUNIZ et al., 2004).

\section{TRACE METALS: EXTRACTION AND ANALYSIS}

Sediment digests were carried out on an inductively coupled plasma atomic emission spectroscope (ICP-AES). Certified marine sediment (MESS-3, National Research Council Canada-NRCC) was used as a reference material, and blanks were processed and analysed simultaneously. All metal concentration data refer to total concentrations unless otherwise specified and are expressed in terms of dry weight.

\section{ORGANIC MARKERS AND CONTAMINANTS}

\section{EXTRACTION AND FRACTIONING}

The analytical procedure adopted for hydrocarbon analyses was that fully described by UNEP (1992). Approximately $20 \mathrm{~g}$ of sediment was Soxhlet extracted over $8 \mathrm{~h}$ using $80 \mathrm{~mL}$ of a mixture of dichloromethane (DCM) and n-hexanes (1:1) A mixture of surrogates (hexadecene and eicosene to non-aromatic hydrocarbons (NAHs) and naphthalene-d8, acenaphthene-d10, phenanthrene-d10, chrysene-d12, and perylene-d12 to PAHs) was added before each blank and sample extraction. The DCM/n-hexanes extract was purified by column chromatography using $5 \%$ deactivated alumina (1.8 g) and silica (3.2 g). The elution was done with $10 \mathrm{~mL}$ of $\mathrm{n}$-hexanes (fraction 1 - aliphatic hydrocarbons) and $15 \mathrm{~mL}$ of (3:7) DCM/n-hexane mixture (fraction 2 - PAHs). An aliquot of $1 \mu \mathrm{L}$ of each extract was injected for gas chromatographic analysis.

Sterol analysis was based on a method described by KAWAKAMI and MONTONE (2002). More than $20 \mathrm{~g}$ of sediment from each site was extracted using a Soxhlet system for $8 \mathrm{~h}$ with $70 \mathrm{~mL}$ of ethanol. The $5 \alpha$-cholestane was used as surrogate and added before each blank and sample extraction. The ethanol extract was reduced to ca. $2 \mathrm{~mL}$ by rotoevaporation and purified using column chromatography with $2 \mathrm{~g}$ of $5 \%$ deactivated alumina and elution with $15 \mathrm{~mL}$ of ethanol. The purified extract was dried in a gentle $\mathrm{N} 2$ stream then derivatised by adding $40 \mathrm{~mL}$ of N,O-bis (trimethylsilyltrifluoroacetamide)/ trimethylchlorosilane (BSTFA/TMCS; 99:1) and left for $90 \mathrm{~min}$ in a water bath at approximately $70^{\circ} \mathrm{C}$.

The determination of PCBs and organochlorines was based on a method described by MUNSHI et al. (2004). Sediment samples $(25 \mathrm{~g})$ were Soxhlet extracted with $250 \mathrm{~mL}$ of a mixture of acetone:hexanes (1:1) during 8 h. The sample extracts were concentrated and subjected to silica gel column chromatography for clean-up and the separation of PCB congeners and chlorinated pesticides. PCB-180 was used as an internal standard.

\section{INSTRUMENTAL ANALYSES AND QUALITY ASSURANCE PROCEDURES}

The instrumental analysis procedure adopted for analyses of aliphatic hydrocarbons and sterols has been described by ABREU-MOTA et al. (2014).

The analyses were performed with an Agilent GC model 7890A equipped with a flame ionization detector and an Agilent DB5 capillary fused silica column coated with $5 \%$ diphenyl/dimethylsiloxane $(30 \mathrm{~m}, 0.25 \mathrm{~mm}$ ID and $0.25 \mu \mathrm{m}$ film thickness). Hydrogen was used as 
the carrier gas. The oven temperature for NAHs was programmed from $40{ }^{\circ} \mathrm{C}$, holding for $2 \mathrm{~min}, 40-60{ }^{\circ} \mathrm{C}$ at $20{ }^{\circ} \mathrm{C} \mathrm{min}$ min $^{-1}$, then to $250{ }^{\circ} \mathrm{C}$ at $5{ }^{\circ} \mathrm{C} \mathrm{min}{ }^{-1}$, and finally to $320^{\circ} \mathrm{C}$ at $6^{\circ} \mathrm{C} \mathrm{min}^{-1}$, where this temperature was held for $20 \mathrm{~min}$. For sterols analysis, the oven temperature was programmed from 40 to $240{ }^{\circ} \mathrm{C}$ at $10{ }^{\circ} \mathrm{C} \mathrm{min}^{-1}$, then to 245 ${ }^{\circ} \mathrm{C}$ at $0.25{ }^{\circ} \mathrm{C} \mathrm{min}{ }^{-1}$, holding for $5 \mathrm{~min}$, and finally to 300 ${ }^{\circ} \mathrm{C}$ at $10{ }^{\circ} \mathrm{C} \mathrm{min}{ }^{-1}$, holding for $5 \mathrm{~min}$. Compounds were individually identified by matching retention times with results from standard mixtures of (C10-C40) n-alkanes and sterols within the range of 0.25 to $10.0 \mu \mathrm{g} \mathrm{L}^{-1}$.

The instrumental analysis procedure adopted for PAHs was described by MARTINS et al. (2011b). The analyses were performed with an Agilent GC model 6890 coupled to an Agilent Mass Spectrometer Detector (model 5973) and an Ultra-2 capillary fused silica column coated with $5 \%$ diphenyl/dimethylsiloxane $(30 \mathrm{~m}, 0.32 \mathrm{~mm}$ ID and $0.25 \mu \mathrm{m}$ film thickness). Helium was used as the carrier gas. The temperature program was the same as that used for the aliphatic hydrocarbons. The data acquisition was undertaken in the SIM mode and the Agilent Enhanced Chemstation G1701 CA was used to perform the measurements. Compounds were identified by matching retention times and ion mass fragments with results from standard mixtures of PAHs (NIST 2260) within the range of 0.10 to $1.50 \mu \mathrm{g} \mathrm{L}^{-1}$.

The determination of PCBs and OCPs was performed by gas chromatography (Perkin Elmer Clarus 500) equipped with electron capture detection (ECD), using a DB-5 column (30 m, $0.25 \mathrm{~mm}$ ID and $0.25 \mu \mathrm{m}$ film thickness). The PCBs and OCPs were identified by comparison of the retention times of chromatographic peaks of samples with external standard solutions of known composition and concentrations (Mix-19 to PCBs, and Mix-5 and Mix-71 to OCPs; purchased from Dr. Ehrenstofer Laboratories, Germany). For the quantification, calibration curves were prepared at different concentrations within the range of 1 to $200 \mathrm{ng} \mu \mathrm{L}^{-1}$.

Procedural blanks were performed for this group of samples, and no peaks interfered with the analyses of target compounds. Surrogate recoveries ranged from 55 to $70 \%$ (NAHs), $70-116 \%$ (PAHs), 83 to $117 \%$ (faecal sterols) and 70-99\% (PCBs and pesticides). The detection limits (DL) were obtained from three times the standard deviation in seven replicates of method blanks (WADE and CANTILLO, 1994). They were $0.001 \mu \mathrm{g} \mathrm{g}^{-1}$ for (C10-C40) n-alkanes, $0.01 \mu \mathrm{g} \mathrm{g}^{-1}$ for sterols and $0.5 \mathrm{ng} \mathrm{g}^{-1}$ for the PAHs analyzed (MARTINS et al., 2012b) and $1 \mathrm{ng} \mathrm{g}^{-1}$ (OCPs and PCBs). Measured concentrations of target aliphatic hydrocarbons and sterols in the reference material provided by the International Atomic Energy Agency (IAEA) were within $90-110 \%$ of the certified values.

\section{DATA ANALYSES}

Austral summer and winter concentrations of metals, n-alkanes, as well as total aliphatic and PAHs were compared using Student's $t$-test. Pearson linear correlation analyses were performed to determine the degree of relationship between the variables studied (ZAR, 1999). The variables were previously transformed $(\log X+1)$ to give the best approximation to normality. The relationships between every pair of variables were also explored using four different models of regression analysis (linear, logarithmic, exponential and geometric) in order to obtain the best fit between them.

\section{RESULTS}

\section{SURFACE SEDIMENT CHARACTERISTICS}

Modern sediments in the study area were dominated by mud fractions $(<63 \mu \mathrm{m})$ with little contribution of sand particles (Table 1). At all the stations analysed, the percentages of silt+clay were higher than $90 \%$. Mud content only correlated significantly with the total organic matter (TOM) content (Table 2, Fig. 2). The best-fitting model between mud and TOM contents was the geometric one, which explained $35 \%$ of the TOM variation, observed.

All sampling stations showed a thin (lower than $1 \mathrm{~cm}$ ) oxic layer (estimated visually through the discontinuity redox layer), and in several stations sediments were completely anoxic (Sts. C, D, E, and F).

The total organic matter content was variable (Table 1), and ranged between 6.98 and $13.5 \%$ (Sts. B and E respectively, both in the summer sampling campaign). The higher values were recorded in the innermost harbor area. There were no significant statistical differences between the two sampling periods related to the organic content of the sediments. TOM correlated positively with the percentage of mud, proteins, silver, total sterols and faecal steroids (Table 2). The best models fitted for TOM and PRT and total sterols were the geometric ones, and explained 57 and $68 \%$ of variance respectively (Fig. 2).

Sediment phytopigment concentrations were also variable (Table 1), with elevated values in the summer period. The Chlor- $a$ /Pheo ratio was always lower than 1.0, and showed the high concentrations of degraded material. 
Table 1. Variables analysed in surface sediments at eight sampling stations in Summer and Winter. TOM = total organic matter; $\mathrm{Chl} \mathrm{a}=$ chlorophyll $\mathrm{a}$; Phaeopig $=$ phaeopigments $\mathrm{CHO}=$ total carbohydrates; $\mathrm{PRT}=$ total proteins. Mean values are reported.

\begin{tabular}{lcccccccc}
\hline Variables/sites & $\mathrm{A}$ & $\mathrm{B}$ & $\mathrm{C}$ & $\mathrm{D}$ & $\mathrm{E}$ & $\mathrm{F}$ & $\mathrm{G}$ & $\mathrm{H}$ \\
\hline Summer period & & & & & & & & \\
Sand (\%) & 1.05 & 7.1 & 2.9 & 3.28 & 1.03 & 0.9 & 1.38 & 2.91 \\
Mud (\%) & 98.95 & 92.9 & 97.1 & 96.72 & 98.97 & 99.1 & 98.62 & 97.09 \\
TOM (\%) & 8.22 & 6.98 & 11.14 & 10.76 & 13.5 & 13.13 & 8.82 & 8.42 \\
Chl a & 2.29 & 2.94 & 3.24 & 2.8 & 2.86 & 3.05 & 2.18 & 2.8 \\
Phaeopig & 2.18 & 31.48 & 19.51 & 18.85 & 13.01 & 32.89 & 18.1 & 19.26 \\
CHO & 2.87 & 0.67 & 9.06 & 8.55 & 6.64 & 4.92 & 4.68 & 10.36 \\
PRT & 13.03 & 5.43 & 19.72 & 22.17 & 22.02 & 14.89 & 11.88 & 19.92 \\
PRT/CHO & 4.54 & 8.1 & 2.17 & 2.59 & 3.32 & 3.02 & 2.54 & 1.92 \\
Winter period & & & & & & & 1.27 & 1.19 \\
Sand (\%) & 0.95 & 1.01 & 1.18 & 5.76 & 2.03 & 1.09 & 98.73 & 98.81 \\
Mud (\%) & 99.05 & 98.99 & 98.82 & 94.24 & 97.97 & 98.91 & 10.43 & 9.45 \\
TOM (\%) & 10.01 & 9.56 & 10.95 & 9.56 & 12.11 & 10.71 & 10.93 \\
Chl a & 0.2 & 0.3 & 0.5 & 0.7 & 1.1 & 4.9 & 0.9 & 0.92 \\
Phaeopig & 0.45 & 1.2 & 2.1 & 4.21 & 6.54 & 6.11 & 4.56 & 4.12 \\
CHO & 0.88 & 0.45 & 0.9 & - & 0.73 & 0.5 & 0.11 & 0.78 \\
PRT & 15.13 & 18.78 & 22.43 & 19.13 & 26.37 & 20.37 & 20.58 & 17.64 \\
PRT/CHO & 17.16 & 41.47 & 24.81 & - & 36.13 & 41.11 & 195.63 & 22.68 \\
\hline
\end{tabular}

Chlorophyll- $a$ and phaeopigments were positively correlated as well as phaeopigments and carbohydrate contents (Table 2). Phaeopigments were also positively correlated with total aliphatics and the unresolved complex mixture (UCM) (Table 2).

Carbohydrate concentrations varied between 0.11 $\mathrm{mg} \mathrm{g}^{-1}$ (dry sediment) (St. G/winter) and $10.36 \mathrm{mg} \mathrm{g}^{-1}$ at St. H/summer. Protein concentrations showed values between 5.43 (St. B/summer) and $26.37 \mathrm{mg} \mathrm{g}^{-1}$ (St. E/ winter). The PRT:CHO ratio ranged between 1.92 and 195.63, at Sts. H/summer and $\mathrm{G} /$ winter, indicating hypertrophic to eutrophic conditions at all the stations. The trophic state of the stations was evaluated following DELL'ANNO et al. (2002) on the basis of both protein and carbohydrate trophic thresholds: hypertrophic $\left(\mathrm{PRT}>4.0 \mathrm{mg} \mathrm{g}^{-1}\right.$; $\mathrm{CHO}>7.0 \mathrm{mg} \mathrm{g}^{-1}$; PRT:CHO > 1), eutrophic (PRT 1.5-4.0 mg g ${ }^{-1}$; CHO 5.0-7.0 $\mathrm{mg} \mathrm{g}^{-1}$, PRT:CHO > 1) and meso-oligotrophic (PRT $<1.5 \mathrm{mg}$ $\mathrm{g}^{-1} ; \mathrm{CHO}<5.0 \mathrm{mg} \mathrm{g}^{-1}$, PRT:CHO $\left.<1\right)$. Based on total protein (PRT) concentrations the majority of the stations were classified as hypertophic, while total carbohydrates (CHO) indicated meso-oligotrophic and eutrophic conditions at most of the sampling stations. Also an important variation between surveys was observed for $\mathrm{CHO}$ contents, values being higher in summer. $\mathrm{CHO}$ correlated positively with n-alkanes, while PRT presented a positive correlation with some metals $(\mathrm{Cu}$, $\mathrm{Cr}$ and $\mathrm{Ag}$ ), total sterols and faecal steroids (Table 2). Figure 2 shows the best models fitted for PRT content and $\mathrm{Cu}, \mathrm{Cr}$ and total sterols, which explained 52, 66 and $71 \%$ of variance respectively (Fig. 2).

\section{TRACE METALS}

The concentrations of the metals analysed are shown in Table 3. The relative abundance of these elements was: $\mathrm{Zn}>\mathrm{Cu}>\mathrm{Cr}>\mathrm{Pb}>\mathrm{Ni}>\mathrm{Ag}$. Some metals showed their highest values at the innermost harbor stations and at the mouth of the streams, indicating the proximity of the sources of different types of chemical discharges. The total amounts of metals analyzed differed from those registered 12 years earlier at the same sampling location for most of the sites studied (Fig. 3).

Cadmium (Cd) always showed values below the detection limits of the technique. Zinc ( $\mathrm{Zn}$ ) ranged between 79.72 and $508.7 \mu \mathrm{g} \mathrm{g}^{-1}$ (up-stream Pantanoso and $\mathrm{H}$ respectively, both in the summer survey). At the mouth of Miguelete stream, high $\mathrm{Cd}$ values were also recorded. Temporal differences were not visualized. 


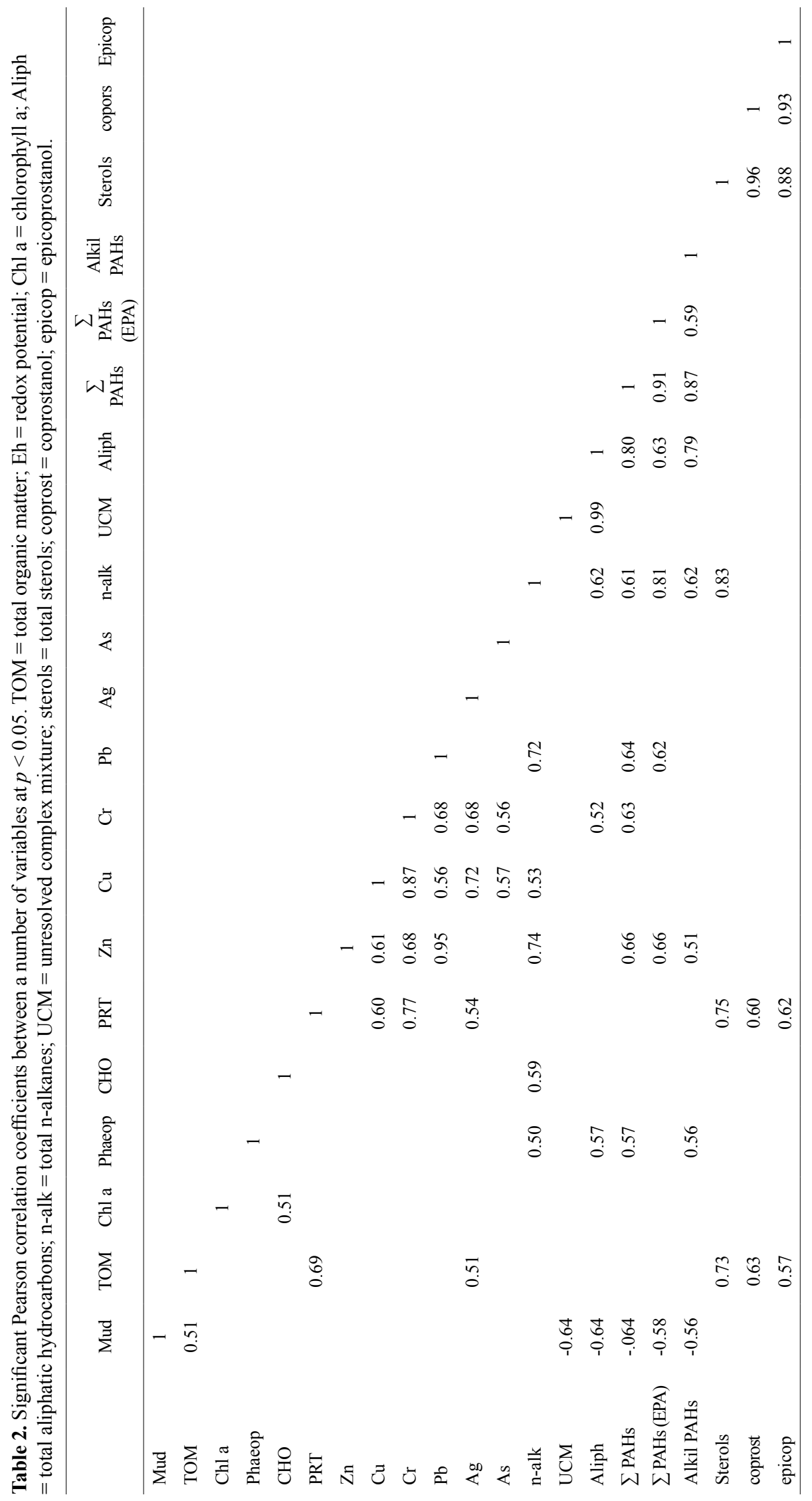



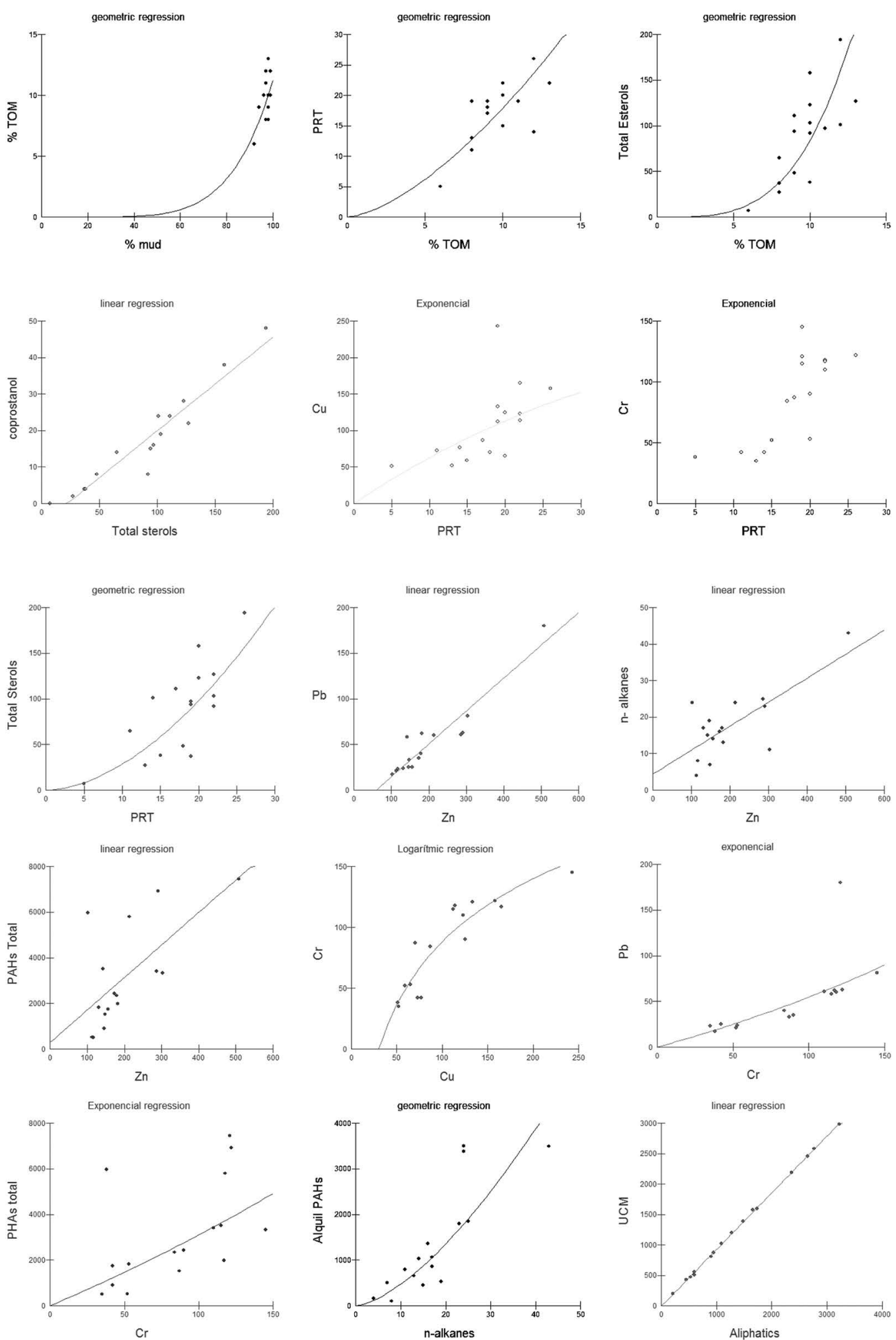

Figure 2. Main relationships among variables studied at Montevideo Harbour considering the two surveys. The most significant regression is shown for each pair of variables, showing the model that best fitted. Units of each variable are as shown in table 1 and 3 to 7. 
Table 3. Concentrations of metals, in $\mu \mathrm{g} \mathrm{g}^{-1}$, in surface sediments collected in Montevideo Harbour and streams, Uruguay. Detection limit (DL) and threshold effect level (TEL) and probable effect level (PEL) values for each metal are also shown. $<$ below DL.

\begin{tabular}{|c|c|c|c|c|c|c|c|}
\hline sites/metals & $\mathrm{Cd}$ & $\mathrm{Zn}$ & $\mathrm{Cu}$ & $\mathrm{Cr}$ & $\mathrm{Ni}$ & $\mathrm{Pb}$ & $\mathrm{Ag}$ \\
\hline Pantanoso upstream & $<$ & 79.72 & 36.70 & 21.78 & 13.50 & 12.76 & $<$ \\
\hline Pantanoso mouth & $<$ & 175.75 & 135.32 & 212.10 & 19.99 & 52.79 & 0.73 \\
\hline Miguelete upstream & $<$ & 105.08 & 54.73 & 37.65 & 14.39 & 32.22 & $<$ \\
\hline Miguelete mouth & $<$ & 285.90 & 203.29 & 106.23 & 14.75 & 107.52 & 1.52 \\
\hline \multicolumn{8}{|l|}{ Summer period } \\
\hline A & $<$ & 117.42 & 52.74 & 35.97 & 22.51 & 23.99 & 0.36 \\
\hline B & $<$ & 102.23 & 51.26 & 38.21 & 28.42 & 17.45 & $<$ \\
\hline $\mathrm{C}$ & $<$ & 142.76 & 112.51 & 115.42 & 22.75 & 58.87 & 1.02 \\
\hline $\mathrm{D}$ & $<$ & 214.10 & 114.11 & 118.48 & 24.14 & 60.72 & 0.63 \\
\hline $\mathrm{E}$ & $<$ & 286.60 & 123.56 & 110.20 & 23.71 & 61.82 & 1.07 \\
\hline $\mathrm{F}$ & $<$ & 156.80 & 77.11 & 42.68 & 23.62 & 25.42 & $<$ \\
\hline G & $<$ & 146.98 & 73.67 & 42.72 & 25.99 & 25.98 & $<$ \\
\hline $\mathrm{H}$ & $<$ & 508.70 & 133.04 & 121.01 & 24.53 & 180.22 & 0.65 \\
\hline \multicolumn{8}{|l|}{ Winter period } \\
\hline A & $<$ & 113.98 & 59.93 & 52.72 & 27.19 & 21.68 & $<$ \\
\hline B & $<$ & 148.71 & 70.00 & 87.50 & 23.70 & 33.15 & $<$ \\
\hline $\mathrm{C}$ & & 182.34 & 165.34 & 117.43 & 24.56 & 62.34 & 1.16 \\
\hline D & $<$ & 303.60 & 243.30 & 145.83 & 26.43 & 81.09 & 1.26 \\
\hline $\mathrm{E}$ & $<$ & 291.40 & 158.15 & 122.83 & 25.36 & 63.85 & 1.21 \\
\hline $\mathrm{F}$ & $<$ & 173.11 & 125.20 & 90.19 & 24.81 & 35.13 & 0.50 \\
\hline G & $<$ & 131.08 & 65.00 & 53.00 & 21.81 & 24.95 & $<$ \\
\hline $\mathrm{H}$ & $<$ & 179.50 & 87.20 & 84.85 & 27.53 & 40.63 & 0.46 \\
\hline DL $\left(\operatorname{ugg~g}^{-1}\right)$ & 3 & 0.2 & 1 & 1 & 1 & 3 & 0.2 \\
\hline TEL & 0.7 & 124 & 18.7 & 52.3 & 15.9 & 30.2 & - \\
\hline PEL & 4.2 & 271 & 108 & 160 & 43 & 112 & - \\
\hline
\end{tabular}

Copper $(\mathrm{Cu})$ showed higher values at the mouth of the streams and in the inner harbour area (Table 3), the lowest value being 36.70 and the highest $208.39 \mu \mathrm{g} \mathrm{g}^{-1}$. Chromium (Cr) ranged between 21.78 (up-stream Station in the Pantanoso stream) and $212.10 \mu \mathrm{g} \mathrm{g}^{-1}$ (Station Pantanoso mouth), and non-significant temporal differences were recorded between the surveys. Nickel $(\mathrm{Ni})$ presented a fairly homogeneous distribution in the study area, especially in the harbor area, with values around $20 \mu \mathrm{g} \mathrm{g}^{-1}$ and more uniform values in the winter survey.

Lead concentrations varied widely between $12.76 \mu \mathrm{g} \mathrm{g}^{-1}$ (St. Pantanoso up-stream) and $180.22 \mu \mathrm{g} \mathrm{g}^{-1}$ (St. H summer) (Table 4). Although summer values were higher than those of the winter survey, there were no overall differences between surveys. Finally, silver showed the lowest levels in the entire study area, with the only exception being at the station at the mouth of the Miguelete, and generally concentrations were below the detection limit of the technique $\left(0.2 \mu \mathrm{g} \mathrm{g}^{-1}\right)$.

Several metals correlated significantly with the other environmental variables (Table 2). The strongest correlations were found between $\mathrm{Cu}$ and PRT, $\mathrm{Cr}$ and PRT, $\mathrm{Cr}$ and $\mathrm{Pb}, \mathrm{Cr}$ and $\mathrm{Cu}, \mathrm{Cr}$ and total PAHs, $\mathrm{Zn}$ and $\mathrm{Pb}, \mathrm{Zn}$ and n-alkanes and also $\mathrm{Zn}$ and total PAHs (Fig. 2). These results suggest a common source of the metals and the other contaminants studied.

Comparing the results with those values recorded 12 years earlier (MUNIZ et al., 2004), most of the metals analyzed decreased in concentration (notably $\mathrm{Pb}, \mathrm{Cr}$ and $\mathrm{Zn}$ ), except for $\mathrm{Cu}$ for which the concentration had a small increment in the harbor sediments (Fig. 3).

\section{Aliphatic AND POLYCYCLIC AROMATIC HYDROCAR-} BONS

Total aliphatic hydrocarbon levels ranged from 451.4 to $3225 \mathrm{mg} \mathrm{g}^{-1}$ in the summer and 210.0 to $2360 \mathrm{mg} \mathrm{g}^{-1}$ 
A

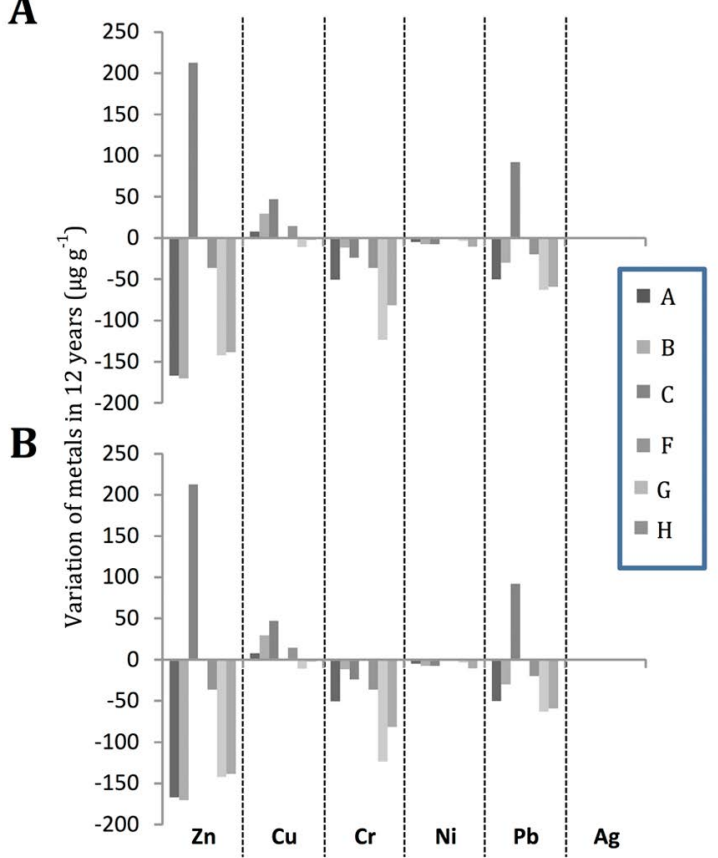

Figure 3. Differences of metal concentrations (concentration 1998-concentration 2010) among sediment samples (station A to $\mathrm{H}$ except D an E) in Montevideo Harbour, (A) Summer, (B) Winter.

in the winter (Table 4). These concentrations were higher in summer than in winter. For the majority of stations, n-alkanes showed maximum and minimum values at the same stations as total aliphatics, as indicated by the strong correlation value (Table 2). The lowest values of total n-alkanes and total aliphatic hydrocarbons in the area were recorded at station $\mathrm{A}$, at the mouth of the harbor area, in the most open portion of the harbor, both in summer and winter surveys. Also a significantly positive correlation between total aliphatics and UCM was observed (Table 2, Fig. 2).

The carbon preference index (CPI) was around 1.0 (Table 4), showing that $\mathrm{n}$ alkanes from Montevideo Harbour originated mostly from petroleum. The pristane/ phytane ratio for most samples was lower than 1.0 (Table 4), indicating petrogenic inputs.

The extremely high proportion of the UCM in all the samples is a clear indication of oil pollution. The UCM/n -alkanes ratio has been used as a marker for petroleum inputs, and a value above 4.0 represents petroleum related sources of the compound (SIMONEIT, 1984). In all the study samples this ratio is above 4.0. Also UCM values correlated positively with total PAHs, total 16 EPA PAHs and Alkylated PAHs (Table 2, Fig. 2).

Total PAH concentrations ranged between 517.8 and 6913.7 and 507.3 and $7458.4 \mathrm{ng} \mathrm{g}^{-1}$ in the winter and summer survey respectively (Table 5 ). In both surveys, the lowest was recorded at station A in both surveys, and the highest at station $\mathrm{H}$. The total concentrations of the $16 \mathrm{PAHs}$ considered by the EPA as priority pollutants (åPAHs $16 \mathrm{EPA}$ ) were also variable. Values were between 303.8 and $3261.6 \mathrm{ng} \mathrm{g}^{-1}$ in the summer and between 310.7 and $4621.1 \mathrm{ng} \mathrm{g}^{-1}$ in the winter (Table 5), but they positively correlated with the UCM, total PAHs, total 16 EPA PAHs and Alkylated PAHs (Table 2).

In both surveys, the lowest concentration of alkylated aromatic compounds (Alkylated PAHs) was recorded at station $\mathrm{A}$, while the highest occurred in the sediments of stations B and E, in summer and winter respectively (Table 5). There was also a clear dominance of PAHs of higher molecular weight (4-6 aromatic rings) compared to those of lower weight (2-3 aromatic rings) (Table 5). The ratios used in the present study to differentiate the source of PAHs in the environment indicated that petroleum and its derivatives are the main local source.

\section{STEROLS}

In summer, concentrations of total sterols varied between $7.66 \mathrm{mg} \mathrm{g}^{-1}$ (St. B) and $127.0 \mathrm{mg} \mathrm{g}^{-1}$ at station $\mathrm{E}$, while in the winter survey the minimum value was $38.8 \mathrm{mg} \mathrm{g}^{-1}$ (St. A) and the maximum was $194.0 \mathrm{mg} \mathrm{g}^{-1}$ (St. E) (Table 6). Generally, stations of inner Montevideo harbor presented the highest values. Winter values were higher than those of the summer. The highest coprostanol concentrations were found at station E, 22.1 and $48.1 \mathrm{mg}$ $\mathrm{g}^{-1}$ in summer and winter respectively (Table 6).

High correlation coefficients were observed between total sterols, coprostanol, epicoprostanol and coprostanone concentrations. Also total sterols correlated positively with PRT and TOM (Table 2, Fig. 2).

\section{POLYCHLORINATED BIPHENYLS AND ORGANOCHLORINE} PESTICIDES

Total PCB concentrations (sum of PCBs 18, 28, 31, $44,52,101,105,118,170,180$ and 194) in the surface sediments included $\alpha-\mathrm{HCH}, \beta-\mathrm{HCH}, \gamma-\mathrm{HCH}, \mathrm{HCB}$, Aldrin, Endrin, Isodrin, Heptachlor, Heptachlor epoxide-a, Heptachlor epoxide-b, $(\alpha+\gamma)$ Chlordanes, Endosulfan II, Endosulfan I, $p, p^{\prime}-\mathrm{DDE}, o, p$ '-DDD, $p, p^{\prime}-\mathrm{DDD}, o, p^{\prime}-$ DDT, $p, p$ '-DDT, Methoxychlor and Mirex.

The concentrations of OCs followed the order: PCB $>\Sigma$ Chlordanes (the sum of heptachlor and its epoxide, $(\alpha+\gamma$-chlordane $)>\Sigma$ Drins (the sum of Aldrin, Endrin and Isodrin) $>\Sigma \mathrm{HCH}$ (sum of $\alpha-\mathrm{HCH}, \beta-\mathrm{HCH}$ and $\gamma-\mathrm{HCH}$ ) 
Table 4. Concentrations of aliphatic hydrocarbons, in $\mu \mathrm{g} \mathrm{g}^{-1}$, and selected ratios in surface sediments collected in Montevideo Harbour, Uruguay.

\begin{tabular}{lcccccccc}
\hline parameters/sites & $\mathrm{A}$ & $\mathrm{B}$ & $\mathrm{C}$ & $\mathrm{D}$ & $\mathrm{E}$ & $\mathrm{F}$ & $\mathrm{G}$ & $\mathrm{H}$ \\
\hline Summer period & & & & & & & & \\
Total n-alkanes & 8.35 & 24.51 & $\mathrm{na}$ & 24.89 & 25.32 & 14.83 & 19.21 & 43.67 \\
Total aliphatic & 451.4 & 3225 & $\mathrm{na}$ & 2768 & 2652 & 1086 & 943 & 1738 \\
UCM & 429.8 & 2980 & $\mathrm{na}$ & 2580 & 2454 & 1021 & 872 & 1592 \\
CPI 25-35 & 2.72 & 2.07 & & 1.55 & 1.76 & 1.71 & 1.82 & 1.06 \\
pristane/phytane & 0.77 & 1.09 & $\mathrm{nc}$ & 1.12 & 1.14 & 0.96 & 1.07 & 1.05 \\
UCM/Total Alkanes & 51.5 & 121.6 & $\mathrm{nc}$ & 103.7 & 96.9 & 68.9 & 45.4 & 36.5 \\
Winter period & & & & & & & & \\
Total n-alkanes & 4.64 & 7.72 & 13.73 & 11.30 & 23.90 & 16.86 & 17.11 & 17.83 \\
Total aliphatic & 210.0 & 601.6 & 1479 & 1275 & 2360 & 902.6 & 533.8 & 599.8 \\
UCM & 196.0 & 560.2 & 1387 & 1197 & 2191 & 808.6 & 472.4 & 505.1 \\
CPI 25-35 & 2.52 & 2.28 & 1.62 & 2.25 & 1.66 & 1.89 & 2.04 & 1.64 \\
pristane/phytane & 0.90 & 0.78 & 0.81 & 0.75 & 1.01 & 1.04 & 1.04 & 0.92 \\
UCM/Total Alkanes & 42.2 & 72.6 & 101.0 & 106.0 & 91.7 & 48.0 & 27.6 & 28.3 \\
\hline
\end{tabular}

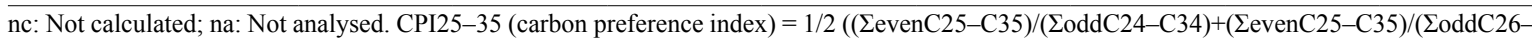
C36)).

Table 5. Polycyclic aromatic hydrocarbons, in $\mathrm{ng}^{-1}$, and selected ratios in surface sediments collected in Montevideo Harbour, Uruguay.

\begin{tabular}{|c|c|c|c|c|c|c|c|c|}
\hline parameters/sites & A & B & $\mathrm{C}$ & $\mathrm{D}$ & $\mathrm{E}$ & $\mathrm{F}$ & G & $\mathrm{H}$ \\
\hline \multicolumn{9}{|l|}{ Summer period } \\
\hline$\sum$ PAHs & 507.3 & 5957.9 & na & 5799.5 & 3400.4 & 1733.8 & 897.6 & 7458.4 \\
\hline$\sum$ PAHs (16 EPA) & 343.4 & 2115.1 & na & 2086.2 & 1295.7 & 594.8 & 303.8 & 3261.6 \\
\hline Alkyl-PAHs & 99.3 & 3498.2 & na & 3377.6 & 1847.9 & 1026.3 & 534.5 & 3493.3 \\
\hline$\sum$ PAHs (2-3 rings) & 37.4 & 330.0 & na & 325.2 & 153.7 & 84.2 & 48.2 & 1219.1 \\
\hline$\sum$ PAHs (4-6 rings) & 370.6 & 2129.8 & na & 2096.7 & 1398.8 & 623.3 & 314.9 & 2746.1 \\
\hline Ant/178 & 0.25 & 0.17 & $\mathrm{nc}$ & 0.14 & 0.25 & 0.20 & 0.23 & 0.11 \\
\hline $\mathrm{Fl} / \mathrm{Fl}+\mathrm{Py}$ & 0.50 & 0.48 & $\mathrm{nc}$ & 0.46 & 0.44 & 0.40 & 0.41 & 0.52 \\
\hline $\mathrm{BzA} / 228$ & 0.41 & 0.36 & $\mathrm{nc}$ & 0.35 & 0.33 & 0.28 & 0.30 & 0.34 \\
\hline IP/IP + Bghi & 0.54 & 0.58 & $\mathrm{nc}$ & 0.59 & 0.56 & 0.51 & 0.49 & 0.54 \\
\hline \multicolumn{9}{|l|}{ Winter period } \\
\hline$\sum$ PAHs & 517.8 & 1522.6 & 1987.8 & 3322.0 & 6913.7 & 2424.5 & 1815.0 & 2337.8 \\
\hline$\sum$ PAHs (16 EPA) & 310.7 & 862.7 & 1123.9 & 2151.8 & 4621.1 & 911.7 & 832.5 & 1101.5 \\
\hline Alkyl-PAHs & 157.3 & 507.4 & 655.6 & 790.5 & 1798.9 & 1366.0 & 864.3 & 1064.2 \\
\hline$\sum$ PAHs (2-3 rings) & 43.6 & 112.6 & 122.4 & 194.1 & 2932.9 & 127.7 & 110.6 & 146.7 \\
\hline$\sum$ PAHs (4-6 rings) & 316.9 & 902.6 & 1209.8 & 2337.4 & 2181.8 & 930.8 & 840.1 & 1126.9 \\
\hline Ant/178 & 0.26 & 0.16 & 0.22 & 0.19 & 0.11 & 0.09 & 0.11 & 0.17 \\
\hline $\mathrm{Fl} / \mathrm{Fl}+\mathrm{Py}$ & 0.46 & 0.41 & 0.42 & 0.47 & 0.46 & 0.41 & 0.44 & 0.40 \\
\hline $\mathrm{BzA} / 228$ & 0.42 & 0.39 & 0.32 & 0.38 & 0.32 & 0.30 & 0.35 & 0.29 \\
\hline IP/IP + Bghi & 0.50 & 0.52 & 0.50 & 0.53 & 0.53 & 0.50 & 0.49 & 0.48 \\
\hline
\end{tabular}

HCB, quite similar to the results found in another subtropical estuary in South America (COMBI et al., 2013a).
PCBs were detected in all the samples analysed in both seasons, except at station A, where the levels were below the limit of detection. The stations sampled in the 
Table 6. Concentrations of fecal and total sterols, in $\mu \mathrm{g} \mathrm{g}^{-1}$, and selected ratios in surface sediments collected in Montevídeo Harbour, Uruguay.

\begin{tabular}{lcccccccc}
\hline sterols/sites & $\mathrm{A}$ & $\mathrm{B}$ & $\mathrm{C}$ & $\mathrm{D}$ & $\mathrm{E}$ & $\mathrm{F}$ & $\mathrm{G}$ & $\mathrm{H}$ \\
\hline Summer period & & & & & & & & \\
coprostanol & 2.04 & 0.58 & $\mathrm{na}$ & 8.22 & 22.1 & 24.2 & 14.1 & 4.39 \\
epicoprostanol & 0.26 & $<\mathrm{LD}$ & $\mathrm{na}$ & 0.64 & 1.49 & 1.33 & 0.62 & 0.66 \\
Total sterols * & 27.0 & 7.66 & $\mathrm{na}$ & 92.0 & 127.0 & 101.4 & 65.4 & 37.3 \\
Ratio I & 0.41 & 0.60 & $\mathrm{nc}$ & 0.69 & 0.70 & 0.80 & 0.73 & 0.71 \\
Ratio II & 0.13 & $\mathrm{nc}$ & $\mathrm{nc}$ & 0.08 & 0.07 & 0.05 & 0.04 & 0.15 \\
Winter period & & & & & & & & \\
coprostanol & 4.20 & 8.26 & 19.0 & 15.2 & 48.1 & 38.6 & 28.9 & 24.9 \\
epicoprostanol & 0.20 & 1.12 & 1.10 & 1.40 & 3.20 & 2.52 & 2.04 & 1.33 \\
Total sterols * & 38.8 & 48.5 & 103.2 & 94.3 & 194.0 & 158.1 & 123.4 & 111.6 \\
Ratio I & 0.62 & 0.80 & 0.75 & 0.78 & 0.78 & 0.83 & 0.85 & 0.83 \\
Ratio II & 0.05 & 0.14 & 0.06 & 0.09 & 0.07 & 0.07 & 0.07 & 0.05 \\
\hline
\end{tabular}

nc: Not calculated; na: Not analysed. * Total sterols: Sum of coprostanol, epicoprostanol, dehydrocholesterol, cholesterol, cholestanol, campesterol, stigmasterol, sitosterol, sitostanol and dinosterol. Ratio I = coprostanol/(coprostanol + cholestanol); Ratio II = epicoprostanol/coprostanol.

Table 7. Concentration of polychlorinated biphenyls (PCBs) and chlorinated pesticides, in ng g-1 from surface sediments collected in Montevideo Harbour, Uruguay.

\begin{tabular}{|c|c|c|c|c|c|c|c|c|}
\hline parameters/sites & $\mathrm{A}$ & B & $\mathrm{C}$ & $\mathrm{D}$ & $\mathrm{E}$ & $\mathrm{F}$ & G & $\mathrm{H}$ \\
\hline \multicolumn{9}{|l|}{ Summer period } \\
\hline$\Sigma \mathrm{HCH}$ & & & & & & & na & \\
\hline $\mathrm{HCB}$ & & & & & & 1.3 & na & \\
\hline$\Sigma$ Drins & & & 16.1 & & & 1.9 & na & \\
\hline$\Sigma$ Chlordanes & & & 1.1 & & & 3.5 & na & \\
\hline$\Sigma$ Endosulfan & & & & & & & na & \\
\hline$\Sigma$ DDT & & & & & & & na & \\
\hline Methoxychlor & & & & & & & na & \\
\hline Mirex & & & & & & & na & \\
\hline$\Sigma$ OCPs & & & 17.2 & & & 6.7 & na & \\
\hline$\Sigma$ PCBs & & 27.9 & 32.8 & 53.1 & 89.1 & 66.5 & na & 15.2 \\
\hline \multicolumn{9}{|l|}{ Winter period } \\
\hline$\Sigma \mathrm{HCH}$ & & & 8.9 & & & & & 9.7 \\
\hline $\mathrm{HCB}$ & & & & & & 4.7 & & \\
\hline$\Sigma$ Drins & & & 1.3 & & & & & \\
\hline$\Sigma$ Chlordanes & & & 31.1 & & & & & \\
\hline \multicolumn{9}{|l|}{$\Sigma$ Endosulfan } \\
\hline \multicolumn{9}{|l|}{$\Sigma$ DDT } \\
\hline \multicolumn{9}{|l|}{ Methoxychlor } \\
\hline \multicolumn{9}{|l|}{ Mirex } \\
\hline$\Sigma \mathrm{OCPs}$ & & & 41.3 & & & 4.7 & & 9.7 \\
\hline$\Sigma$ PCBs & & 25.9 & 22.5 & 50.2 & 21.0 & 1.5 & 16.8 & 15.8 \\
\hline
\end{tabular}

summer period presented relatively higher concentrations of PCBs than in winter, with maximum concentrations of 89.1 (station E) and $50.2 \mathrm{ng} \mathrm{g}^{-1}$ (station D), respectively.
PCB 170 was the predominant compound, found in $67 \%$ of the samples analysed. PCBs 28, 31, 44, 101 and 194 were not observed in this study. 
OCPs were found in $33 \%$ of the samples analysed. Stations $\mathrm{C}$ and $\mathrm{F}$ presented OCPs in both seasons, while OCPs occurred only in the winter at station $\mathrm{H}$. Maximum concentrations were found at station $\mathrm{C}$ with 41.3 (winter) and $17.2 \mathrm{ng} \mathrm{g}^{-1}$ (summer). The OCPs Endosulfan I, Endosulfan II, p,p'-DDE, o,p'-DDD, p,p'-DDD, o,p'-DDT, p,p'-DDT, Methoxychlor and Mirex were not found in the samples analysed.

\section{DISCUSSION}

This integrative study of sediment physicochemical variables, including contaminants produced by anthropogenic activities, showed that the environmental health of the study area is weak, presenting a low ecological quality of the sediments.

Silty sediments, such as those recorded in the present study, show that the study area can be characterised as a low energy environment, where particle deposition occurs. Only stations near the mouths of the streams have an important contribution of sands, denoting areas of higher energy. A comparable pattern had previously been reported by several authors (CARDELLINO and FERRANDO, 1969; AYUP, 1986; MUNIZ et al., 2002; MUNIZ et al., 2004). Silt-clay sediments ( $<63 \mathrm{~mm})$ have important ecological and environmental consequences related to the resident biota and deposition of particles (pollutants, for example). They could be traps for toxic substances which in turn could be easily resuspended by the maritime traffic and storms (shallow environments), potentially making them more bioavailable for the benthic biota. Also the results of the thickness of the oxygenated layer confirmed the depositional character of the study area, especially as regards the harbor sediments. These results are in agreement with those of the organic matter content, showing that the innermost areas of the harbor are also the most organically enriched. Since the prevalent water circulation in the bay is clockwise (PLATA et al., 1992; SANTORO et al., 2013), all the substances entering the bay through the streams and from continental sources will finally be deposited in these innermost areas.

Although phytopigment concentrations were very variable, it is important to highlight the highest values at the stations in the innermost portion of the study area, near to the electrical power plant (Central Battle) in the shallowest portion of the Bay. In this case the waste-water (at higher temperature than the surrounding water column) could be enhancing the activity of primary producers. Chlorophyll a is used frequently as an estimator of fresh food for deposit-feeders of the bottom sediments, and also the ratio chlor a/pheopig is useful for that. In the present case, these values, always lower than 1 , are a clear indication of degraded organic matter prevalent on the surface bottom sediments (MUNIZ et al., 2006; ALBANO et al., 2013). This pattern has been previously recorded for the study area and shows the intense microbial activity present due to the excess of organic matter. The sediment is an important site for the degradation of organic matter, including the microphytobenthic biomass. In agreement with previous results, high values of sediment phytopigments are evident across the whole area (see MUNIZ et al., 2004), with higher (not always significantly so) values in the summer. This last pattern is a common feature of temperate estuaries such as the Montevideo Bay ecosystem. Chlor a concentrations observed in the present study are typical of eutrophic environments where anthropogenic influence is high (COTANO and VILLATE, 2006; PUSCEDDU et al., 2007; VENTURINI et al., 2012).

According to DELL'ANNO et al. (2002), using a classification based on protein content, all the stations could be considered hypertrophic. Also according to carbohydrate content, stations $\mathrm{C}, \mathrm{D}$ and $\mathrm{H}$ could, in summer, be considered hypertrophic. These concentrations were in the same range as those reported for areas severely impacted by anthropogenic activities. According to DANOVARO et al. (1999) protein concentrations in the sediments reflect the productivity of a system, there being a progressive diminution of these compounds and an enrichment in carbohydrates under more oligotrophic conditions. The protein enrichment observed in the present case is indicative of a high degree of eutrophication.

The lack of correlation between different trace metal concentrations and granulometric fractions might be explained by the great homogeneity of sediment size across the study area. Additionally, no correlation was observed between organic matter and metal concentrations, reflecting the high percentage of organic matter in the sediment. However, we can observe higher values near the mouths of the streams and in some areas of the harbor, indicating the potential inputs of several compounds into the system. The spatial distribution of metal concentrations is useful to assess the possible sources of enrichment and to identify "hot spot" areas with high metal concentrations (ZHOU et al., 2007).

Even though $\mathrm{Cd}$ levels are low, this metal can be toxic below the detection limit (ca. $2 \mathrm{ug} \mathrm{g}^{-1}$ ). When the Cd levels 
of this study are compared to those of Muniz et al. (2004), we observe significant differences (at station B). This metal mainly originates in the fertilizer and electroplating industries, but it is not widely used in Uruguay. FEOLA et al. (1997) have thus reported that Cd contamination in the study area should not be extreme.

$\mathrm{Zn}$ is commonly associated with both domestic and industrial effluents. The comparison of $\mathrm{Zn}$ values between this study and Muniz et al. (2004) indicates that $\mathrm{Zn}$ depletion over time has been remarkable as the latest values were $50 \%$ lower.

Observed values of $\mathrm{Cu}$ are similar to those reported by MUNIZ et al. (2004) and reached moderate to high toxic levels (LUOMA and RAINBOW, 2008). Due to the strong geochemical association of this element with organic matter, an increase in organic content would lead to an increase in the metal burden in the harbor. This is supported by the strong relationship between maximum values of $\mathrm{Cu}$ concentration and organic matter content. Because of the close affinity with organic matter, it is difficult to determine the origin of the $\mathrm{Cu}$, as the metal fraction of the sediment may come from other places and get deposited together with the organic fraction in internal zones where a high sedimentation rate is observed.

The low $\mathrm{Cr}$ values are remarkable, being almost 50\% lower than those reported by MUNIZ et al. (2004 and references therein, Fig. 3). The highest concentrations were recorded in the internal zone of the harbour, and the mouth of Pantanoso Stream that receives waste from the leather tanning industry. A paleoenvironmental study has shown a decrease of this metal during the last decade (GARCÍA-RODRÍGUEZ et al., 2010). Re-location of tanneries to other regions of the country might explain the drop in Cr levels.

No temporal differences were observed for $\mathrm{Ni}$, and a high homogeneity during the winter sampling was recorded. The recorded small difference between the samples of the mouth and the upper reaches of the streams is remarkable. This fact would indicate that the inputs of this metal are not associated with the streams entering Montevideo Bay. Instead, such inputs could be associated with battery factories and the oil refinery.

The levels of $\mathrm{Pb}$ are usually associated with urban and industrial waste and city transport. We observed important differences with regard to MUNIZ et al. (2004) (i.e. a decrease from average values of 85 to $51 \mathrm{mg} \mathrm{g}^{-1}$ ), which is in close agreement with other studies (GARCÍARODRÍGUEZ et al., 2010; MUNIZ et al., 2011). Such studies attribute the decrease in $\mathrm{Pb}$ to the use of $\mathrm{Pb}$-free fuel. $\mathrm{Pb}$ is not essential to biological processes and it can be highly toxic to both aquatic organisms and human beings.

The station-by-station analysis of metals indicates that there is low temporal variability, but also that two main station groups can be distinguished. The first corresponds to the internal harbor area and the stations located at the mouth of the streams. The second group corresponds to those stations at the entrance of the harbor localized in a more open area (i.e., stations A and B).

When our present data are compared to those of the internal harbor reported by HYTSA(2007), it is remarkable that in the vicinity of station $\mathrm{E}$, the concentration of heavy metals in the most ancient surface sediments is higher than in the most modern ones, thus confirming the decreasing trend in heavy metal levels.

The environmental risk of sediment contamination by heavy metals can be assessed by comparing chemical data (i.e. analytical measurements) with literature data on the toxicity of the elements in the sediment to organisms (LONG et al., 1995). In this sense standard sediment quality data based on empirical analysis and experiments are needed. Such analyses have been developed for several contaminants, and the minimum level of harmful concentrations for biological communities have been established (LONG et al., 1995; MACDONALD et al., 1996). Although these data are considered site-specific, and are not intended for regulation purposes, they represent benchmarks for the assessment of biological risk and permit the classification of sediments according to quality. There are several threshold levels which enable this kind of assessment to be undertaken, but the most widely used are TEL and PEL. TEL (Threshold Effect Level) is a reference level of baseline effect below which no adverse biological damage is expected. PEL (Probable Effect Level) refers to the probable effect level above which biological damage is to be expected. According to our results, the $\mathrm{Zn}$ and $\mathrm{Cu}$ levels of the internal harbor stations, the mouths of the Pantanoso and Miguelete streams and station $\mathrm{H}$, could cause biological damage. However, the comparison of such levels with those of MUNIZ et al. (2004) indicates that there has been an important decrease in the toxic potential, even though some stations still exhibit critical TEL and PEL values that may represent some biological risk.

The concentrations of aliphatic hydrocarbons (AHs), such as n-alkanes, unresolved complex mixtures (UCM), 
and polycyclic aromatic hydrocarbons (PAHs) in sediments have been used to assess petroleum and petroleum byproduct contamination in coastal environments (SILVA and BÍCEGO, 2010). These molecular geochemical markers can also be derived from natural, diagenetic or anthropogenic sources (ABOUL-KASSIM and SIMONEIT, 1996; WANG et al., 2001).

Generally, the total n-alkane concentrations in unpolluted intertidal and estuarine sediments may not be higher than $10 \mathrm{mg} \mathrm{g}^{-1}$ (VOLKMAN et al., 1992; BOULOUBASSI and SALIOT, 1993). However, concentrations may be two to three times higher where there are significant inputs of $n$-alkanes derived from higher plants. Organic-rich marine sediments may contain up to $100 \mathrm{mg} \mathrm{g}^{-1}$ of total aliphatic hydrocarbons, but concentrations higher than this are usually due to petroleum input.

Values such as those recorded here are a clear indication of petroleum (oil) contamination (VOLKMAN et al., 1992). Additionally, it is important to highlight that present concentrations are higher than those previously recorded in the same area (MUNIZ et al., 2004).

The presence of UCM in all the samples analysed is an indication of chronic contamination (GOUGH and ROWLAND, 1990). The UCM were present in values above $90 \%$ of the total aliphatics suggesting a high degree of anthropogenic contribution including waste petroleum derivatives (READMAN et al., 2002). On the temporal scale, as compared with previous studies, the UCM values also were higher (MUNIZ et al., 2004) indicating a continuous contamination of the study area. The fact that higher values were recorded at the innermost harbour stations, could, again, be explained by the water circulation patterns prevailing in the bay. The main sources of these compounds in the area are, without doubt, the input from the oil refinery and the shipping inside the harbor.

According to the CPI (ABOUL-KASSIM \& SIMONEIT, 1996) values the main source of n-alkanes is petrogenic contamination. This trend has also been observed when analysing the pristano/phytano ratio, with values around and/or above 1.0 (VOLKMAN et al., 1992).

The PAH concentrations were lower than those previously reported for the area (MUNIZ et al., 2004). The values can be considered high and are in the same range as those of highly polluted systems in the northern Atlantic Ocean near Spain (1400 to $4900 \mathrm{ng} \mathrm{g}^{-1}$ ) (ANTIZARLADISLAO, 2009), the Huaihe River in China (60-2230 $\mathrm{ng} \mathrm{g}^{-1}$ ) (FU et al., 2011), and the Santos Estuary, Brazil
(15.400 ng g ${ }^{-1}$ ) (MEDEIROS and BÍCEGO, 2004). The clear predominance of high molecular weight PAHs (4-6 aromatic rings) over those of lower weight (2-3 aromatic rings) PAHs in all the samples analysed denotes pirolitic input (LIU et al., 2008). These inputs, from the incomplete combustion of fossil fuel are those which most persist in the environment (READMAN et al., 2002).

Values of the Ant $/ 178>0.10$ recorded at all the stations of Montevideo Harbor, in both surveys, are indicative of compounds derived from combustion. In the same way, those values between 0.40 and 0.50 for the $\mathrm{Fl} / \mathrm{Fl}+\mathrm{Py}$ ratio, between 0.20 and 0.50 for IP/IP + Bghi ratio and between 0.20 and 0.35 for the $\mathrm{BzA} / 228$ ratio, suggest the presence of both crude oil and compounds derived from its combustion (YUNKER et al., 2002).

Analysing the potential PAH toxicity of the sediments studied shows that almost all the stations presented values above TEL, but below PEL (TEL $=1684 \mathrm{ng} \mathrm{g}^{-1} ; \mathrm{PEL}=16770$ $\mathrm{ng} \mathrm{g}^{-1}$ ) (Table 5). The reduction in toxic PAH concentrations is clear when these are compared with previous data (MUNIZ et al., 2004), when the whole harbor area presented total PAH concentrations around the PEL value, indicating little reduction of toxic compounds in the area.

Coprostanol is formed from the bacterial transformation of cholesterol in the human gut (MURTAUGH and BUNCH, 1967; HATCHER and MCGILLIVARY, 1979). It is the most abundant sterol in human faeces and, consequently, is frequently used as an urban sewage tracer (DAUGHTON, 2012). GONZÁLEZ-OREJA and SAIZ-SALINAS (1998) have suggested that coprostanol concentrations greater than $0.50 \mu \mathrm{g} \mathrm{g}^{-1}$ may be used to indicate sewage contamination. Based on the coprostanol limit mentioned above, all the stations analyzed in both periods presented high sewage contamination, especially in the winter period (sites $\mathrm{E}$, F, G, H). The coprostanol levels (mean $=10.8 \pm 8.8$ and $23.0 \pm 14.0 \mu \mathrm{g} \mathrm{g}^{-1}$; in the summer and winter periods, respectively) in the sediments studied were higher than those at other sites situated near densely populated areas, such as those on the San Pedro Shelf, USA ( $\left.>1.00 \mu \mathrm{g} \mathrm{g}^{-1}\right)$ (MALDONADO et al., 2000), at Sochi, Black Sea, Russia (5.40 $\mu \mathrm{g} \mathrm{g}^{-1}$ ) (READMAN et al., 2005), in Kyeonggi Bay, Korea (3.80 $\mu \mathrm{g} \mathrm{g}^{-1}$ ) (LI et al., 2007), Santos Bay, Brazil (< 0.10-8.51 $\mu_{\mathrm{g} \mathrm{g}^{-1}}$ ) (MARTINS et al., 2008a,b). Diagnostic ratios involving coprostanol and selected sterols, e.g., cholestanol ( $5 \alpha$-cholestan-3 $\beta$-ol) are usually considered in the assessment of sewage contamination. For instance, values for the coprostanol/(coprostanol + cholestanol) between 0.5 and 1.0 are indicative of sewage contamination 
in sediments (LEEMING et al.,1998). With the exception of site A (summer period), all our stations presented values of this ratio higher than 0.5 , confirming the sewage contamination of the study area.

Epicoprostanol, another "faecal" sterol, is present in small amounts in human faeces but can also be produced in anoxic environments such as sewage sludge (MCCALLEY et al., 1981; MUDGE and LINTERN, 1999). It can be used in association with coprostanol as an indicator of the treatment level of the sewage because it is formed during the anaerobic treatment of wastewater (MUDGE and DUCE, 2005). The ratio of epicoprostanol to coprostanol in the study area was $<0.15$ at all sites, indicating sediment contamination by raw sewage.

The maximum PCB levels are below those of more developed and populated areas in Brazil, such as the Santos Estuary (0.03-254 ng g-1; BÍCEGO et al., 2006), and in other areas of the world, such as Sea Lots in Trinidad and Tobago (62-601 ng g-1 ; Mohammed et al., 2011) and Alexandria Harbor in Egypt (0.9-1211 ng g ${ }^{-1}$; BARAKAT et al., 2002). However, the PCB levels are higher than those of Paranaguá Bay, Brazil, another important harbour area in South America (n.d. - 6.65 ng g-1 COMBI et al., 2013).

The data obtained for PCBs was compared with sediment-quality guidelines to assess the sediment potential risk for biota. For this purpose, the thresholdeffects level $\left(\mathrm{TEL}=21.6 \mathrm{ng} \mathrm{g}^{-1}\right)$ and probable-effects level $\left(\mathrm{PEL}=188.8 \mathrm{ng} \mathrm{g}^{-1}\right)$ values were adopted. Above the TEL, adverse effects can be frequent, and above the PEL, adverse effects on biota are to be expected (LONG et al., 1995; MACDONALD et al., 1996). The concentrations exceed the TEL level in at least $50 \%$ of the samples analyzed, and these concentrations may represent a risk to marine organisms.

The most abundant OCPs were chlordanes and the maximum level found in Montevideo Bay was slightly higher those of more developed and populated areas in Brazil, such as Guanabara Bay (0.55-9.93 ng g-1 ; SOUZA et al., 2008), and in other areas of the world, such as Daya Bay in China (0.06-8.80 $\mathrm{ng} \mathrm{g}^{-1}$; ZHOU et al., 2001) and Lake Qarun in Egypt (0.25-21.1 ng g-1 ${ }^{-1}$ BARAKAT et al., 2013), Due to the absence of DDT, contamination by pesticides in the sediment from Montevideo Harbor is not severe.

\section{CONCLUSIONS}

The data here show that the environmental quality of the sediment in the study area is low, with multiple stressors of anthropogenic origin that probably affect the environmental health of the whole ecosystem. Clear changes were observed in sediment samples of the Montevideo harbour in a 12-year temporal comparison. Several trace metals, such as $\mathrm{Pb}, \mathrm{Cr}$ and $\mathrm{Zn}$, reduced in concentration while others such as $\mathrm{Cu}$ and Ni presented no change or only a slight increment. Organic pollutants such as toxic PAHs also showed but slight reduction in their concentrations, but in some places still represent a potential risk for the resident biota. PCB concentrations could represent some risk to marine organisms, since concentrations exceed the TEL.

The lack of strong correlations between hydrocarbons, heavy metals and steroids, as a general trend, could be indicative of the different sources (origins) of these compounds. While $\mathrm{HC}$ are derived principally from the oil refinery, sterols clearly showed the influence of sewage in the study area, which enters the system principally through the two streams and presents a large increase in the winter (rainy period) when the streams' discharges are higher than in summer.

Results indicate that levels of trace elements and petroleum derivatives are changing seasonally and on a long time scale in most areas of the harbour. These findings also indicate a modification in the sedimentation rate, input and/or hydrodynamics of Montevideo harbor when compared with those of previous studies, and should be taken into account for management purposes.

\section{ACKNOWLEDGMENTS}

This study was funded by the Administración Nacional de Puertos (ANP) of Uruguay through the ANP-UdelaR project \#. The authors are very grateful to Catherine Wandsworth (NHM) for metal analysis. PM, NV, EB, FGR and JGA also acknowledge their debt to SNI-ANII. Special thanks are also due to Lic. R. Vallejo (ANP) for his help during the different stages of the project and to the colleagues of Oceanografía \& Ecología Marina (UdelaR) for their important help in the fieldwork and laboratory analysis. C.C. Martins wishes to thank CNPq (Brazilian National Council for Scientific and Technological Development) for the Research Grant (305763/2011-3). The authors would also like to thank BSc. Rafael Bet for assistance with the hydrocarbon and sterol analyses. Special thanks also to Phill S. Rainbow of the Natural 
History Museum (London) for his kindly correction and improvement of the last version of the MS. Special thanks too to two anonymous reviewers whose comments and corrections improved its quality.

\section{REFERENCES}

ABOUL-KASSIM,T.A.T.; SIMONEIT,B.R.T.Lipidgeochemistry of surficial sediments from the coastal environment of Egypt I. Aliphatic hydrocarbons - characterization and sources. Mar. Chem., v. 54, n. 1/2, p. 135-158, 1996.

ABREU-MOTA, M. A.; BARBOZA, C. A. M.; BÍCEGO, M. C.; MARTINS, C. C. Sedimentary biomarkers along a contamination gradient in a human-impacted sub-estuary in Southern Brazil: A multi parameter approach based on spatial and seasonal variability. Chemosphere, v. 103, p. 156-163, 2014.

AIROLDI, L.; BECK, M. W. Loss, status, and trends for coastal marine habitats of Europe. Oceanogr. Mar. Biol. Ann. Rev., v. 45, p. 345-405, 2007.

ALBANO, M. J.; LANA, P. C.; BREMEC, C.; ELIAS, R.; MARTINS, C. C.; VENTURINI, N; MUNIZ, P.; RIVERO, S.; OBENAT, S. Macrobenthos and multi-molecular markers as indicators of environmental contamination in a South American port (Mar del Plata, Southwest Atlantic). Mar. Pollut. Bull., v. 73, n. 1, p. 102-114, 2013.

ANTIZAR-LADISLAO, B. Polycyclic aromatic hydrocarbons, polychlorinated biphenyls, phthalates and organotins in northern Atlantic Spain's coastal marine sediments. J. Environ. Monit., v. 11, n. 1, p. 85-91, 2009.

AYUP, R. N. Comportamento dos sedimentos em suspensão no Río de la Plata exterior e proximidades. Pesquisas, v. 18, p. 39-68, 1986

BARAKAT, A. O.; KIM, M.; QIAN, Y.; WADE, T. L. Organochlorine pesticides and $\mathrm{PCB}$ residues in sediments of Alexandria Harbour, Egypt. Mar. Pollut. Bull., v. 44, n. 12, p. 1426-1434, 2002.

BARAKAT, A. O.; KHAIRY, M.; AUKAILY, I. Persistent organochlorine pesticide and $\mathrm{PCB}$ residues in surface sediments of Lake Qarun, a protected area of Egypt. Chemosphere, v. 90, n. 9, p. 2467-2476, 2013.

BÍCEGO; M. C.; TANIGUCHI, S.; YOGUI, G. T.; MONTONE; R. C.; SILVA, D. A. M.; LOURENÇO, R. A.; MARTINS, C. C.; SASAKI, S. T.; PELLIZARI, V. H.; WEBER, R. R. Assessment of contamination by polychlorinated biphenyls and aliphatic and aromatic hydrocarbons in sediments of the Santos and São Vicente Estuary System, São Paulo, Brazil. Mar. Pollut. Bull. v. 52, p. 1784-1832, 2006.

BOLL, E. S; CHRISTENSEN, J. H; HOLM, P. E. Quantification and source identification of polycyclic aromatic hydrocarbons in sediment, soil, and water spinach from Hanoi, Vietnam. J. Environ. Monit., v. 10, n. 2, p. 261-269, 2010.

BORJA, A.; BALD, J.; FRANCO, J.; LARRETA, J.; MUXIKA, I.; REVILLA, M.; RODRÍGUEZ, J.G.; SOLAUN, O.; URIARTE, A.; VALENCIA, V. Using multiple ecosystem components, in assessing ecological status in Spanish (Basque Country) Atlantic marine waters. Mar. Pollut. Bull., v. 59, n. $1 / 3$, p. 54-64, 2009.

BOYLE, D.; BRIX, K.V.; AMLUIND, H.; LUNDEBYE, A. K.; HOGSTRAND, C.; BURY, N. R. Natural arsenic contaminated diets perturb reproduction in fish. Environ. Sci. Technol., v. 42, p. 5354-5360, 2008.
CADDY, J. F. Marine catchment basin effects versus impacts of fisheries on semi-enclosed seas. ICES J. Mar. Sci., v. 57, n. 3, p. 628-640, 2000.

CARDELlinO, R.; FERRANDO, L. Carta Geológica del Uruguay, segundo segmento. Montevideo: Sector XCVIII. Universidad de la República, Departamento de Publicaciones colección Serie Especial, Montevideo, 1969.

CARDOSO PG, LILLEB $\varnothing$ AI, PEREIRA E, DUARTE AC, PARDAL MA. 2009. Different mercury bioaccumulation kinetics by two macrobenthic species: the bivalve Scrobicularia plana and the polychaete Hediste diversicolor. Mar Environ Res. 68(1):12-8.

COMBI, T.; TANIGUCHI, S.; FIGUEIRA, R. C. L.; MAHIQUES, M. M.; MARTINS, C. C. Spatial distribution and historical input of polychlorinated biphenyls (PCBs) and organochlorine pesticides (OCPs) in sediments from a subtropical estuary (Guaratuba Bay, SW Atlantic). Mar. Pollut. Bull., v. 70, n. 1/2, p. 247-252, 2013.

COMBI, T.; TANIGUCHI, S.; FERREIRA, P. A. L.; MANSUR, A.V.; FIGUEIRA, R. C. L.; MAHIQUES, M. M.; MONTONE, R. C.; MARTINS, C. C. Sources and temporal patterns of polychlorinated biphenyls around a large South American grain shipping port (Paranaguá Estuarine System, Brazil). Arch. Environ. Contam. Toxicol., v. 64, n. 4, p. 573-582, 2013.

COTANO, U., VILLATE, F. Anthropogenic influence on the organic fraction of sediments in two constrasting estuaries: a biochemical approach. Mar. Pollut. Bull., v. 52, n. 4. p. 404-414, 2006.

DANOVARO, R.; DINET, A.; DUINEVELED, G.; TSELEPIDES, A. Benthic response to particulate fluxes in different trophic environments: a comparison between theGulf of Lions-Catalan Sea (W-Mediterranean) and the Cretan Sea (E-Mediterranean). Prog. Oceanogr., v. 44, p. 287-312, 1999.

DANULAT, E; MUNIZ, P; GARCÍA-ALONSO, J; YANNICELLI, B. First assessment of the highly contaminated harbour of Montevideo, Uruguay. Mar. Pollut. Bull., v. 44, n. 6 , p. 554-565, 2002.

DELL'ANNO, A.; MEI, M. L.; PUSCEDDU, A.; DANOVARO, R. Assessing the trophic state and eutrophication of coastal marine systems: a new approach based on the biochemical composition of sediment organic matter. Mar. Pollut. Bull., v. 44, n. 7, p. 611-622, 2002.

DAUGHTON, C. G. Real-time estimation of small-area populations with human biomarkers in sewage. Sci. Total. Environ., v. 414, p. 6-21, 2012.

DUCROTOY, J. P.; ELLIOTT, M. Recent developments in estuarine ecology and management. Mar. Pollut. Bull., v. 53, n. 1/4, p. 1-4, 2006.

ELLIOTT, M.; MARSHALL, S. The biology of fishes in the Humber Estuary. In: JONES, N. V.; ELLIOTT, M. (Eds.). Coastal Zone Topics: Process, Ecology \& Management. The Humber Estuary and adjoining Yorkshire and Lincolnshire Coasts. Kingston upon Hull: Estuarine \& Coastal Sciences Association, 2000. p. 85-95.

FEOLA G DOL I ROSAZZA N SIERRA R GARLATTI A. 1997. Metales pesados en Montevideo, zona costera. IV Simposio Centro Americano y del Caribe en Química Analítica Ambiental y Sanitaria. 22-26 setiembre de 1997. Panamá.

FU, J.; DING, Y. H.; LI, L.; SHENG, S.; WEN, T.; YU, L. J.; CHEN, W.; AN, S. Q.; ZHU, H. L. Polycyclic aromatic hydrocarbons and ecotoxicological characterization of sediments from the Huaihe River, China. J. Environ. Monit., v. 13, n. 3, p. 597-604, 2011. 
GARCÍA-ALONSO, J.; GREENWAY, G. M.; MUNSHI, A.; GÓMEZ, J. C.; MAZIK, K.; KNIGHT, A. W.; HARDEGE, J. D; ELLIOTT, M. Biological responses to contaminants in the Humber Estuary: disentangling complex relationships. Mar. Environ. Res., v. 71, n. 4, p. 295-303, 2011.

GARCÍA-RODRÍGUEZ, F.; HUTTON, M.; BRUGNOLI, E.; VENTURINI, N.; DEL PUERTO, L.; INDA, H.; BRACCO, R.; BURONE, L.; MUNIZ, P. Assessing the effect of natural variability and human impacts on the environmental quality of a coastal metropolitan area (Montevideo Bay, Uruguay). Pan-Amer. J. Aquat. Sci., v. 5, p. 90-99, 2010.

GERCHACOV, S. M.; HATCHER, P. G. Improved technique for analysis of carbohydrates in the sediment. Limnol. Oceanogr., v. 17, p. 938-943, 1972.

GONZÁLEZ-OREJA, J. A.; SAIZ-SALINAS, J. I. Short-term spatio-temporal changes in urban pollution by means of faecal sterols analysis. Mar. Pollut. Bull., v. 36, 11, p. 868-875, 1998.

GORSKI, P. R.; CLECKNER, L. B.; HURLEY, J. P.; SIERSZEN, M. E.; ARMSTRONG, D. E. Factors affecting enhanced mercury bioaccumulation in inland lakes of Isle Royale National Park. USA. Sci. Total. Environ., v. 304, n. 1/3, p.327-348, 2003.

GOUGH, M. A.; ROWLAND, S. J. Characterization of unresolved complex mixtures of hydrocarbons in petroleum. Nature, v. 344, p. 648-650, 1990.

GRAY, J. S.; ELLIOTT, M. Ecology of marine sediments: Science to management. Oxford: Oxford University Press, 2009. 225 p.

HATCHER, P. G.; MCGILLIVARY, P. A. Sewage contamination in the New York BightdCoprostanol as an indicator. Environ. Sci. Technol., v. 13, p. 1225-1229, 1979.

HARTREE, E. F. Determination of proteins: a modification of the Lowry method that give a linear photometric response. Anal. Biochem., v. 48, n. 2, p. 422-427, 1972.

HEIRI, O.; LOTTER, A. F.; LEMCKE. Loss on ignition as a method for estimating organic and carbonate content: reproducibility and comparability of the results. J. Paleolimnol., v. 25, n. 1, p. 101-110, 2001.

HYTSA, 2007. Estudio de impacto ambiental del dragado del canal de acceso, recinto portuario y dragados de mantenimiento del Puerto de Montevideo - Uruguay (ATN/ OC-9912-UR). Análisis sedimentos Muelle C. 8pp. Available at: $<$ http://www.anp.com.uy $>$. [Accessed on: 15 Jun. 2015].

IMM. Intendencia Municipal de Montevideo (IMM), 2008. Evaluación de la Contaminación Industrial. Available at: $<$ http://www.montevideo.gub.uy/sites/default/files/articulo/ infoindustrias 08 o $0 . p d f>$

IMM. Intendencia Municipal de Montevideo (IMM), 2009. Programa de Monitoreo de Agua de Playas y Costa de Montevideo. Informe 2008-2009. Available at: $<\mathrm{http}: / /$ www.montevideo.gub.uy/sites/default/files/articulo/ monitoreoagua_estival0809_0.pdf $>$

KAWAKAMI, S. K.; MONTONE, R. C. An efficient ethanolbased analytical protocol to quantify fecal steroids in marine sediments. J. Braz. Chem. Soc., v. 13, n. 2. p. 226-232, 2002.

KIM, G. B.; MARUYA, K. A.; LEE, R. F.; LEE, J. H.; KOH, C. H.; TANABE, S. Distribution and sources of polycyclic aromatic hydrocarbons in sediments from Kyeonggi Bay, Korea. Mar. Pollut. Bull., v. 38, p. 7-15, 1999.

LAW, R. J.; BISCAYA, J. L. Polycyclic aromatic hydrocarbons (PAH)-Problems and progress in sampling, analysis and interpretation. Mar. Pollut. Bull., v. 29, p. 235-241, 1994.
LEEMING, R.; BATE, N.; NICHOLS, P. D. Discriminating faecal pollution: a case study of stormwater entering Port Phillip Bay, Australia. Water Sci. Technol., v. 38, n. 10, p. $15-22,1998$

LI, D., SHIM, W. J.; DONG, M.; OH, S. H. H. Application of nonylphenol and coprostanol to identification of industrial and faecal pollution in Korea. Mar. Pollut. Bull., v. 54, n. 1, p. 101-107, 2007.

LI, X.; LIU, L.; WANG, Y.; LUO, G.; CHEN, X.; YANG, X.; GAO, B.; HE, X. Integrated assessment of heavy metal contamination in sediments from a coastal industrial basin, NE China. PLoS One, v. 7, n. 6, p. e39690, 2012.

LIM, D. I.; JUNG, H. S.; KIM, K. T.; SHIN, H. H.; JUNG, S. W. Sedimentary records of metal contamination and eutrophication in Jinhae-Masan Bay, Korea. Mar. Pollut. Bull., v. 64, n. 11. p. 2542-2548, 2012.

LIU, Y; CHEN, L.; JIANFU, Z.; QINGHUI, H.; ZHILIANG, Z.; HONGWEN, G. Distribution and sources of polycyclic aromatic hydrocarbons in surface sediments of rivers and an estuary in shanghai, china. Environ. Pollut., v. 154, n. 2, p. 298-305, 2008.

LONG, E. R.; MACDONALD, D. D.; SMITH, S. L.; CALDER, F. D. Incidence of adverse biological effects within ranges of chemical concentrations in marine and estuarine sediments. Environ. Manag., v. 19, p. 81-97, 1995.

LORENZEN, C. J. Determination of chlorophyll and pheopigments: spectrophotometric equations. Limnol. Oceanogr., v. 12, p. 343-346, 1967.

LOTZE, H. K.; LENIHAN, H.S.; BOURQUE, B. J.; BRADBURY, R.; COOKE, R. G.; KAY, M. C.; KIDWELL, S. M.; KIRBY, M. X.; PETERSON, C. H.; JACKSON, J. B. C. Depletion, degradation, and recovery potential of estuaries and coastal seas. Science, v. 312, n. 5781, p. 1806-1809, 2006.

MCDONALD, D. D.; CARR, R. S.; CALDER, F. D.; LONG, E. R.; INGERSOLL, C. G. Development and evaluation of sediment quality guidelines for Florida coastal waters. Ecotoxicology, v. 5, n. 4, p. 253-278, 1996.

MALDONADO, C.; VENKATESAN, M. I.; PHILLIPS, C. R.; BAYONA, J. M. Distribution of Trialkylamines and coprostanol in San Pedro shelf sediments adjacent to a sewage outfall. Mar. Pollut. Bull., v. 40, p. 680-687, 2000.

MARTINS, C. C.; MAHIQUES, M. M.; BÍCEGO, M. C.; FUKUMOTO, M. M.; MONTONE, R. C. Comparison between anthropogenic hydrocarbons and magnetic susceptibility in sediment cores from the Santos Estuary, Brazil. Mar. Pollut. Bull., 54, n. 2, p. 240-246, 2007.

MARTINS, C. C.; AGUIAR, S. N.; BÍCEGO, M. C.; MONTONE, R. C. Sewage organic markers in surface sediments around the Brazilian Antarctic station: results from the 2009/10 austral summer and historical tendencies. Mar. Pollut. Bull., v. 64, n. 12, p. 2867-2870, 2012.

MARTINS, C. C.; BÍCEGO, M. C.; FIGUEIRA, R. C. L.; ANGElli, J. L. F.; COMBI, T.; GALliCE, W. C.; MANSUR, A.V.; NARDES, E.; ROCHA, M. L.; WISNIESKI, E.; CESCHIM, L. M. M.; RIBEIRO, A. P. Multi-molecular markers and metals as tracers of organic matter inputs and contamination status from an Environmental Protection Area in the SW Atlantic (Laranjeiras Bay, Brazil). Sci. Total Environ., v. 412, p. 1-11, 2012a. 
MARTINS, C. C.; BÍCEGO, M.C.; MAHIQUES, M. M.; FIGUEIRA, R. C. L.; TESSLER, M. G.; MONTONE, R. C. Polycyclic aromatic hydrocarbons (PAHs) in a large South American industrial coastal area (Santos Estuary, Southeastern Brazil): sources and depositional history. Mar. Pollut. Bull., v. 63, p. 452-458, 2011b.

MARTINS, C. C.; BRAUN, J. A. F.; SEYFFERT, B. H.; MACHADO, E. C.; FILLMANN, G. Anthropogenic organic matter inputs indicated by sedimentary fecal steroids in a large South American tropical estuary (Paranaguá estuarine system, Brazil). Mar. Pollut. Bull., v. 60, n. 11, p. 2137-2143, 2010 .

MARTINS, C. C.; CABRAL, A. C.; CINTRA, S. C. T. B.; DAUNER, A. L. L.; SOUZA, F. M. An integrated evaluation of molecular marker indices and linear alkylbenzenes (LABs) to measure sewage input in a subtropical estuary (Babitonga Bay, Brazil). Environ. Pollut., v. 188, p. 71-80, 2014.

MARTINS, C. C.; SEYFFERT, B. H.; BRAUN, J. A. F.; FILLMANN, G. Input of organic matter in a large South American tropical estuary (Paranaguá Estuarine System, Brazil) indicated by sedimentary sterols and multivariate statistical approach. J. Braz. Chem. Soc., v. 22, n. 8. p. 15851594, 2011a.

MARTINS, C. C.; FERREIRA, J. A.; TANIGUCHI, S.; MAHIQUES, M. M.; BÍCEGO, M. C.; MONTONE, R. C. Spatial distribution of sedimentary linear alkylbenzenes and faecal steroids of Santos Bay and adjoining continental shelf, SW Atlantic, Brazil: origin and fate of sewage contamination in the shallow coastal environment. Mar. Pollut. Bull., v. 56, n. 7, p. 1353-1376, 2008a.

MARTINS, C. C.; GOMES, F. B. A.; FERREIRA, J. A.; MONTONE, R. C. Organic markers of sewage contamination in surface sediments from Santos Bay, São Paulo. Quím. Nova, v. 31, n. 5, p. 1008-1014, 2008b.

MCCALLEY, D.V.; COOKE, M.; NICKLESS, G. Effect of sewage treatment on faecal sterols. Water Res., v. 15, p. 1019$1025,1981$.

MEDEIROS, P. M.; BÍCEGO, M. C. Investigation of natural and anthropogenic hydrocarbon inputs in sediments using geochemical markers. I. Santos, SP, Brazil. Mar. Pollut. Bull., v. 49, p. 761-769, 2004.

MOHAMMED, A.; PETERMAN, P.; ECHOLS, K.; FELTZ, K.; TEGERDINE, G.; MANOO, A.; MARAJ, D.; AGARD, J.; ORAZIO, C. Polychlorinated biphenyls (PCBs) and organochlorine pesticides (OCPs) in harbor sediments from Sea Lots, Port-of-Spain, Trinidad and Tobago. Mar. Pollut. Bull., v. 62, n. 6, p. 1324-1332, 2011.

MUDGE, S. M.; DUCE, C. E. Identifying the source, transport path and sinks of sewage derived organic matter. Environ. Pollut., v. 136, n. 2, p. 209-220, 2005.

MUDGE, S. M.; LINTERN, D. G. Comparison of sterol biomarkers for sewage with other measures in Victoria Harbour, B.C., Canada. Estuar. Coast. Shelf Sci., v. 48, n. 1, p. 27-38, 1999.

MUDGE, S. M.; SEGUEL, C. G. Organic contamination of San Vicente Bay, Chile. Mar. Pollut. Bull., v. 38, p. 1011-1021, 1999.

MUNIZ, P.; VENTURINI, N.; MARTÍNEZ, A. Physico-chemical and pollutants of the benthic environment of the Montevideo Coastal Zone, Uruguay. Mar. Pollut. Bull., v. 44, p. 962-968, 2002.
MUNIZ, P.; PIRES-VANIN, A. M. S.; MARTINS, C. M.; MONTONE, R. C.; BÝCEGO, M. C. Trace metals and organic compounds in the benthic environment of a subtropical embayment (Ubatuba Bay, Brazil). Mar. Pollut. Bull., v. 52, n. 2, p. 1098-1105, 2006.

MUNIZ, P.; DANULAT, E.; YANNICELLI, B.; GARCÍAALONSO, J.; MEDINA, G.; BÍCEGO, M. C. Assessment of contamination by heavy metals and petroleum hydrocarbons in sediments of Montevideo Harbour (Uruguay). Environ. Int., v. 29, n. 8, p. 1019-1028, 2004.

MUNIZ,P.;VENTURINI,N.;HUTTON,M.;KANDRATAVICIUS, N.; PITA, A.; BRUGNOLI, E.; BURONE, L.; GARCIARODRIGUEZ, F. Ecosystem health of Montevideo coastal zone: a multi approach using some different benthic indicators. J. Sea Res., v. 65, n. 1, p. 38-50, 2011.

MUNSHI, A. B.; SCHULZ-BULL, D.; SCHNEIDER, R.; ZUBERI, R. Organochlorine concentration in various fish from different locations of Karachi coast. Mar. Pollut. Bull., v. 49, n. 78, p. 597-601, 2004.

MURTAUGH, J. J.; BUNCH, R. L. Sterols as a measure of fecal pollution. J. Water. Pollut. Control. Fed., v. 39, p. 404-409, 1964.

PENG, S.; QIN, X.; SHI, H.; ZHOU, R.; DAI, M.; DING, D. Distribution and controlling factors of phytoplankton assemblages in a semi-enclosed bay during spring and summer. Mar. Pollut. Bull., v. 64, n. 5, p. 941-948, 2012.

PENG, X.; ZHANG, G.; BIXIAN, M.; HU, J.; LI, K.; WANG, $Z$. Tracing anthropogenic contamination in the Pearl River estuarine and marine environment of South China Sea using sterols and other organic molecular markers. Mar. Pollut. Bull., v. 50, n. 8, p. 856-865, 2005.

PLATA, A.; KURUCZ, A.; VERA, C.; SUÁREZ, R.; URES, C.; PINTOS, J. Circulación y renovación del agua en la Bahía de Montevideo. Progress Report, Project URU/8/007. Viena: Organismo Internacional de Energia Atómica (OIEA), 1992.

PUSCEDDU, A.; GAMBI, C.; MANINI, E.; DANOVARO, R. Trophic state, ecosystem efficiency and biodiversity of transitional aquatic ecosystems: analysis of environmental quality based on different benthic indicators. Chem. Ecol., v. 23 , p. $505-515,2007$.

READMAN, J. W.; FILLMANN, G.; TOLOSA, I., BARTOCCI, J.; VILLENEUVE, J. P.; CATINNI, C.; MEE, L. D. Petroleum and PAH contamination of the Black Sea. Mar. Pollut. Bull., v. 44, n. 1, p. 48-62, 2002.

READMAN, J. W.; FILLMANN, G.; TOLOSA, I.; BARTOCCI, J.; MEE; L. D. The use of steroid markers to assess sewage contamination of the Black Sea. Mar. Pollut. Bull., v, 50, n. 3, p. 310-318, 2005.

RICE, D. L. The detritus nitrogen problem: new observations and perspectives from organic geochemistry. Mar. Ecol. Prog. Ser., v. 9, p. 153-162, 1982.

SANTORO, P.; FOSSATI M.; PIEDRA-CUEVA, I. Characterization of Circulation Patterns in Montevideo Bay (Uruguay). J. Coastal. Res., v. 29, n. 4, p. 819-835, 2013.

SHI, J.; LI, G.; WANG, P. Anthropogenic influences on the tidal prism and water exchanges in Jiaozhou Bay, Qingdao. China J. Coast. Res., v. 27, n. 1, p. 57-72, 2011.

SILVA, D A M.; BÍCEGO, M. C. Polycyclic aromatic hydrocarbons and petroleum biomarkers in São Sebastião Channel, Brazil: assessment of petroleum contamination. Mar. Environ. Res., v. 69, n. 5, p. 277-286, 2010. 
SOUZA, A. S.; TORRES, J. P. M.; MEIRE, R. O.; NEVES, R. C.; COURI, M. S.; SEREJO, C. S. Organochlorine pesticides (OCs) and polychlorinated biphenyls (PCBs) in sediments and crabs (Chasmagnathus granulata, Dana, 1851) from mangroves of Guanabara Bay, Rio de Janeiro State, Brazil. Chemosphere, v. 73, p. 186-192, 2008.

SÜNBACK, K. Microphytobenthos on sand in shallow brackish water, Öresund Sweden. Primary production, chlorophyll a content and species composition (Diatoms) in relation to some ecological factors. Doctoral Thesis. Department of Systematic Botany, University of Lund, Sweden. LUNDS/ (NBBS-1006), 1983. 209 p.

SUGUIO, K. Introdução à sedimentologia. São Paulo: Edgard Blücher/EDUSP, 1973. 317 p.

UNEP (United Environment Programme). Determinations of petroleum hydrocarbons in sediments. Reference methods for marine pollution studies, $1991.97 \mathrm{p}$.

UNEP (United Nations Environment Programme).World development report 2012. Making new technologies work for human development, 2012.

VENTURINI, N.; BÍCEGO M; TANIGUCHI S; SASAKI S; GARCÍA-RODRÍGUEZ F; BRUGNOLI E; MUNIZ, P. A multi-molecular marker assessment of organic pollution in shore sediments from the Río de la Plata Estuary, SW Atlantic. Marine Pollution Bulletin, v.: 91 2, p.: 461 - 475, 2015

VENTURINI, N.; PITA, AL.; BRUGNOLI, E.; GARCÍARODRÍGUEZ, F.; BURONE, L.; KANDRATAVICIUS, N.; HUTTON, M.; MUNIZ, P. Benthic trophic status of sediments in a metropolitan area (Rio de la Plata estuary): Linkages with natural and human pressures. Estuarine, Coastal. Shelf Sci., v. 112, n. 20, p. 139-152, 2012.
VOLKMAN, J. K; HOLDWORTH, D. G; NEILL, G. P.; BAVOR, H. J. Identification of natural, anthropogenic and petroleum hydrocarbons in aquatic sediments. Sci. Total Environ., v. 112, p. 203-19, 1992.

WADE, T. L.; CANTILLO, A.Y. Use of standards and reference materials in the measurement of hydrocarbon residues. Chemistry workbook. NOOA technical memorandum NOS ORCA 77. Maryland: Silver Spring, 1994.

WANG, Z.; FINGAS, M.; SIGOUIN, L. Characterization and identification of a "mystery" oil spill from Quebec. (1999). J. Chromatogr. A. v. 909, p. 155-69, 2001.

WAYCOTT, M.; DUARTE, C. M.; CARRUTHERS, T. J. B.; ORTH, R. J.; DENNISON, W. C.; OLYARNIK, S.; CALLADINE, A.; FOURQUREAN, J. W.; HECK, K. L.; HUGHES, A. R.; KENDRICK, G. A.; KENWORTHY, W. J.; SHORT, F. T.; WILLIAMS, S. L. Accelerating loss of seagrasses across the globe threatens coastal ecosystems. Proc. Natl. Acad. Sci. USA., v. 106, p. 12377-12381, 2009.

YUNKER, M. B.; MACDONALD, R. W.; VINGARZAN, R.; MITCHELL, R. H.; GOYETTE, D.; SYLVESTRE, S. PAHs in the Fraser River basin: a critical appraisal of PAH ratios as indicators of PAH source and composition. Org. Geochem., v. 33, p. 489-515, 2002.

ZAR, J. H. Biostatistical analysis. 4.ed. New Jersey: Prentice Hall, 1999.

ZHOU, J. L.; MASKAOUI, K.; QIU, Y. W.; HONG, H. S.; WANG, Z. D. Polychlorinated biphenyl congeners and organochlorine insecticides in the water column and sediments of Daya Bay, China. Environ. Pollut., v. 113, p. 373-384, 2001.

ZHOU, F.; GUO, H. C.; HAO, Z. J. Spatial distribution of heavy metals in Hong Kong's marine sediments and their human impacts: a GIS-based chemometric approach. Mar. Pollut. Bull., v. 54, n. 9, p. 1372-1384, 2007a. 